\title{
Optimizing and purifying extracellular amylase from soil bacteria to inhibit clinical biofilm-forming bacteria
}

\author{
Rokaia Elamary ${ }^{\text {Corresp., } 1}$, Wesam M Salem ${ }^{\text {Corresp. } 1}$ \\ ${ }^{1}$ Department of Botany and Microbiology, South Valley University, Qena, Egypt \\ Corresponding Authors: Rokaia Elamary, Wesam M Salem \\ Email address: roka.elamary_88@yahoo.com, wesam.salem@svu.edu.eg
}

Background. Bacterial biofilms have become a major threat to human health. The objective of this study was to isolate amylase-producing bacteria from soil to determine the overall inhibition of certain pathogenic bacterial biofilms. Methods. We used serial dilution and the streaking method to obtain a total of 75 positive amylase isolates. The starch-agar plate method was used to screen the amylolytic activities of these isolates, and we used morphological and biochemical methods to characterize the isolates. Optimal conditions for amylase production and purification using Sephadex G-200 and SDS-PAGE were monitored. We screened these isolates' antagonistic activities and the purified amylase against pathogenic and multi-drug-resistant human bacteria using the agar disk diffusion method. Some standard antibiotics were controlled according to their degree of sensitivity. Finally, we used spectrophotometric methods to screen the antibiofilm 24 and $48 \mathrm{~h}$ after application of filtering and purifying enzymes in order to determine its efficacy at human pathogenic bacteria. . Results. The isolated Bacillus species were Bacillus megaterium (26.7\%), Bacillus subtilis (16\%), Bacillus cereus (13.3\%), Bacillus thuringiesis (10.7\%), Bacillus lentus (10.7\%), Bacillus mycoides (5.3\%), Bacillus alvei (5.3\%), Bacillus polymyxa (4\%), Bacillus circulans (4\%), and Micrococcus roseus (4\%). Interestingly, all isolates showed a high antagonism to target pathogens. $B$. alevi had the highest recorded activity $(48 \mathrm{~mm})$ and $B$. polymyxa had the lowest recorded activity $(12 \mathrm{~mm})$ against Staphylococcus aureus (MRSA) and Escherichia coli, respectively. On the other hand, we detected no antibacterial activity for purified amylase. The supernatant of the isolated amylase-producing bacteria and its purified amylase showed significant inhibition for biofilm: $93.7 \%$ and $78.8 \%$, respectively. This suggests that supernatant and purified amylase may be effective for clinical and environmental biofilm control. Discussion. Our results showed that soil bacterial isolates such as Bacillus sp. supernatant and its purified amylase are good antibiofilm tools that can inhibit multidrug-resistant former strains. They could be beneficial for pharmaceutical use. While purified amylase was effective as an antibiofilm, the isolated supernatant showed better results. 
1

Optimizing and purifying extracellular amylase from soil bacteria to inhibit clinical

biofilm-forming bacteria

2 Rokaia B. Elamary ${ }^{1}$; and Wesam M. Salem ${ }^{\text {Corresp., } 1 *}$

3

${ }^{1}$ Department of Botany and Microbiology, South Valley University, Qena, Egypt

4 Corresponding Author 1:

5 Wesam Salem ${ }^{1 *}$

6 Email address: wesam.salem@svu.edu.eg

7 Corresponding Author 2:

Rokaia B. Elamary ${ }^{1 *}$

Email address: roka.elamary_88@yahoo.com

8

9

10

11

12

13

14

15

16

17

18

19

20

21

22

23

24

25

26

Peer) reviewing PDF | (2020:03:46812:3:1:NEW 17 Sep 2020) 
27 Abstract

28 Background. Bacterial biofilms have become a major threat to human health. The objective of 29 this study was to isolate amylase-producing bacteria from soil to determine the overall inhibition 30 of certain pathogenic bacterial biofilms.

31 Methods. We used serial dilution and the streaking method to obtain a total of 75 positive 32 amylase isolates. The starch-agar plate method was used to screen the amylolytic activities of 33 these isolates, and we used morphological and biochemical methods to characterize the isolates. 34 Optimal conditions for amylase production and purification using Sephadex G-200 and SDS35 PAGE were monitored. We screened these isolates' antagonistic activities and the purified 36 amylase against pathogenic and multi-drug-resistant human bacteria using the agar disk diffusion method. Some standard antibiotics were controlled according to their degree of sensitivity. Finally, we used spectrophotometric methods to screen the antibiofilm 24 and $48 \mathrm{~h}$ after 39 55 56 application of filtering and purifying enzymes in order to determine its efficacy at human pathogenic bacteria. .

Results. The isolated Bacillus species were Bacillus megaterium (26.7\%), Bacillus subtilis (16\%), Bacillus cereus (13.3\%), Bacillus thuringiesis (10.7\%), Bacillus lentus (10.7\%), Bacillus mycoides (5.3\%), Bacillus alvei (5.3\%), Bacillus polymyxa (4\%), Bacillus circulans (4\%), and Micrococcus roseus (4\%). Interestingly, all isolates showed a high antagonism to target pathogens. B. alevi had the highest recorded activity $(48 \mathrm{~mm})$ and B. polymyxa had the lowest recorded activity (12 mm) against Staphylococcus aureus (MRSA) and Escherichia coli, respectively. On the other hand, we detected no antibacterial activity for purified amylase. The supernatant of the isolated amylase-producing bacteria and its purified amylase showed significant inhibition for biofilm: $93.7 \%$ and $78.8 \%$, respectively. This suggests that supernatant and purified amylase may be effective for clinical and environmental biofilm control.

Discussion. Our results showed that soil bacterial isolates such as Bacillus sp. supernatant and its purified amylase are good antibiofilm tools that can inhibit multidrug-resistant former strains. They could be beneficial for pharmaceutical use. While purified amylase was effective as an antibiofilm, the isolated supernatant showed better results.

\section{Introduction}


57 Bacterial biofilms have increasingly become a serious threat to human health (Hall-Stoodley et

58

59

60

61

62

63

64

65

66

67

68

69

70

71

72

73

74

75

76

77

78

79

al., 2004; Saber et al., 2017). These substances have a high level of antibiotic resistance and are hosts to immune response stimulants (Rodrigues et al., 2016; Sharma et al., 2019). They also play an essential role in the pathogenicity of several chronic human infections (Parsek \& Singh, 2003). Biofilm removal is a particularly difficult task. The principal method for preventing biofilm formation is applying chemicals or antimicrobials, such as chemical biocides, detergents, and surfactants. Biofilm destruction and prevention are effective methods, as are mechanical removal techniques such as shredding, sonication, freezing, and thawing (de Carvalho, 2007; Kalpana et al., 2012; Elamary et al., 2020). However, because the exopolysaccharide biofilm cells are protected (Kalpana et al., 2012), it is difficult to completely remove biofilms using these methods. Using enzymes is also a good strategy for biofilm removal because enzymes are rabidly biodegradable and environmentally harmless (Xavier et al., 2005). Amylase is a member of the glycosidic hydrolases, which are digestive enzymes that hydrolyze starch glycosidic bonds (Kaur et al., 2012). This family also includes maltotriotic glucose, dextrin, and maltose. Amylase has exhibited excellent antibiotic activity against Pseudomonas aeruginosa and Staphylococcus aureus marine-derived biofilm-forming bacteria (Vaikundamoorthy et al., 2018). Soil is the main part of the terrestrial environment, which is compared with aquatic environments with a large association of microorganisms. Among terrestrial bacteria, Bacillus sp. is the best source of amylase producers, including Bacillus subtilis, Bacillus cereus, and Bacillus polymyxa (El-Fallal et al., 2012; Dash et al., 2015). Bacillus amylase is thermostable, and retains a high pH, osmolarity, and high pressure, which are important for manufacturing (Islam et al., 2017). Antibiotics produced by Bacillus sp. such as bacitracin, gramicidin S, polymyxin, and tyrotricidin have exhibited great efficacy against gram-positive and gram-negative bacteria 
80 (Perez et al., 1992; 1993; Yilmaz et al., 2006). In this study, we identified and isolated Bacillus

81 spp. from soil using morphological and biochemical assays. We compared the antimicrobial

82 activity of these isolates against five human pathogenic strains. We optimized and purified the

83 amylase after determining the optimal temperature, $\mathrm{pH}$, incubation period, and starch levels

84 needed for the greatest purification. Finally, we monitored the antibiofilm activity of the filtrate

85 and purified amylase from these isolates.

86 Materials \& Methods

87 1- Soil sample collection. We collected 100 soil samples during January 2019 from different

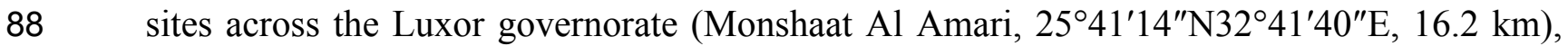

89 Egypt. Samples were collected in sterile plastic bags under aseptic conditions and were

90 transported to the laboratory (Reed and Rigney, 1947). We added 1 gram of soil to $5 \mathrm{ml}$ of

91 tryptic soy broth (Oxoid, Hampshire, United Kingdom), which we modified with 1\% starch

92 to make enrichment broth. Samples were incubated at $37^{\circ} \mathrm{C}$ for $24 \mathrm{~h}$. The landowner,

93 Mohamed El sanousy, approved field sampling.

94 2- Screening and isolation of amylase-producing bacteria. Serial dilution techniques are one

95 of the most precise methods for isolating bacteria from soil (Jamil et al., 2007; Rasooli et al., 96 2008). We performed serial dilutions up to $10^{-7}$. We aseptically transferred $100 \mu 1$ from each 97 dilution, which we spread into tryptic soy agar media fortified with $1 \%$ starch. The plates were 98 incubated at $37^{\circ} \mathrm{C}$ for $24 \mathrm{~h}$ to determine the colony-forming unit $(\mathrm{CFU}) / \mathrm{ml}$. The plates were then 99 flooded with iodine that turns blue when it reacts to unhydrolyzed starch. If the starch was 100 hydrolyzed, a clear halo zone would appear against a dark blue background around the colonies 101 that produce amylase (Gupta et al., 2003; Abd-Elhahlem et al., 2015). We further subcultured 102 bacterial isolates to obtain a pure culture and identified isolates using standard morphological 103 techniques based on colony shape, Gram's staining, spore formation, and biochemical 
104 characterization (Cruickshank et al., 1975; Collins and Lyne, 1984; Koneman et al., 1992;).

105 Isolates were then maintained in a $70 \%$ sterilized glycerol stock at $-70{ }^{\circ} \mathrm{C}$ for further use.

106 3- Selecting isolates for amylase purification. We selected isolates for amylase extraction and

107 purification, as well as for comparing the purified amylase's antibiofilm activity against some

108 human pathogenic bacteria, according to the starch hydrolysis ratio (SHR) that we calculated

109 using the following equation (Pranay et al., 2019):

$110 \mathrm{SHR}=$ clear halo zone diameter $(\mathrm{mm}) /$ colony growth diameter $(\mathrm{mm})$.

111 Isolates were subcultured on starch agar plates, which were incubated for $24 \mathrm{~h}$ at $37^{\circ} \mathrm{C}$. After

112 incubation, the plates were flooded with iodine. Finally, we calculated SHR using the equation 113 above.

114 4- Optimization of amylase production

115 a- Effect of temperature and incubation periods. The starch nutrient medium was prepared 116 and the $\mathrm{pH}$ was adjusted to 7.5. We then inoculated the medium with the tested isolates. The 117 culture was allowed to grow on a rotatory shaker $(250 \mathrm{revs} / \mathrm{min})$ at temperatures ranging from 15 118 to $65^{\circ} \mathrm{C}$ over $48 \mathrm{~h}$. We took $20 \mathrm{ml}$ from each culture at all temperatures and time intervals $(18$, $11924,48,72,96$, and $120 \mathrm{~h}$ ) and centrifuged them to remove the bacterial cells. Finally, the 120 supernatant was collected to assay the amylase activity (Nimisha et al., 2019).

121 b- Effect of $\mathbf{p H}$. We prepared the starch nutrient medium and adjusted the $\mathrm{pH}$ to different values $122(5,6,7,8,9$, and 10). Each isolate was inoculated into a portion of this medium and were grown 123 at $50^{\circ} \mathrm{C}$ for $24 \mathrm{~h}$. We then collected $20 \mathrm{ml}$ from each isolate and applied the same treatment as 124 above to determine amylase activity (Nimisha et al., 2019).

125 c- Effect of starch concentration. All Bacillus isolates were grown on nutrient broth medium 126 with a $\mathrm{pH}$ of 9 , except $B$. subtilis which was grown at a $\mathrm{pH}$ of 7 . Different soluble starch 
127 quantities were added to fresh medium to give final concentrations of $0.1,0.5,1,1.5,2,2.5$, and

$1283 \%$. We inoculated each isolate in this medium at $50^{\circ} \mathrm{C}$ for $24 \mathrm{~h}$ to determine their amylase 129 activity (Nimisha et al., 2019).

130 5- Determining amylase activity under optimum conditions. The assay mixture contained 2 $131 \mathrm{ml}$ of a solution made up of $1 \%$ starch in $50 \mathrm{mM}$ sodium phosphate buffer $(\mathrm{pH} 7)$ and $0.1 \mathrm{ml}$ of 132 enzyme solution. After $10 \mathrm{~min}$. of incubation at $40^{\circ} \mathrm{C}$, we stopped the reaction by adding $2 \mathrm{ml}$ of 133 3,5 dinitrosalicylic acid (DNS) reagent, and heated the tubes at $100^{\circ} \mathrm{C}$ for 5 minutes. The 134 absorbance was measured spectrophotometrically at $540 \mathrm{~nm}$ using a blank containing buffer 135 instead of the culture supernatant. We calculated the amount of reduced sugars from a maltose 136 standard curve (Meyer et al., 1951). Protein was determined using Bradford's (1976) method.

137 6- Enzyme purification

138 a- Ammonium sulfate precipitation. The crude amylase enzyme was brought to $45 \%$ 139 saturation with ammonium sulfate and was kept overnight in a cold room at $4^{\circ} \mathrm{C}$. We removed 140 the precipitate, brought the supernatant to $85 \%$ saturation with ammonium sulfate, and 141 centrifuged it at $8,000 \mathrm{rpm}$ for $10 \mathrm{~min}$ at $4^{\circ} \mathrm{C}$. After collecting the precipitate during this step, we 142 stored it at $4^{\circ} \mathrm{C}$ (Shinde \& Soni, 2014).

143 b- Dialysis. This step was conducted to exclude the ammonium sulfate remains and to 144 concentrate the enzyme. We used the dialysis tubes, which were previously soaked in $0.1 \mathrm{M}$ 145 phosphate buffer ( $\mathrm{pH}$ 6.2), for precipitate dialysis. The precipitate was dissolved in $0.1 \mathrm{M}$ 146 phosphate buffer and was dialyzed against the same buffer (Roe, 2001).

147 c- DEAE Sephadex G-200. The crude enzyme preparations of the six culture filtrates were 148 applied separately to a column of DEAE-Sephadex G-200. The enzyme was eluted with a linear 149 gradient of sodium chloride $(0-0.4 \mathrm{M})$ in $200 \mathrm{ml}$ of sodium phosphate buffer $(0.05 \mathrm{M}$ and $\mathrm{pH}$ 
150 7), the flow rate was adjusted to $1 \mathrm{ml}$ per $1 \mathrm{~min}$., and $200 \mathrm{ml}$ of eluents were collected into 40

151 tubes $(1 \times 7 \mathrm{~cm})$ using an automatic circular fraction collector. We determined enzyme activity

152 and protein concentration in each fraction using the described assay method. Fractions of the

153 highest specific activity were pooled together and kept for further study.

\section{4 d- SDS-PAGE}

155 We carried out polyacrylamide gel electrophoresis according to Laemmli's (1970) method using $15610 \%$ polyacrylamide gel. Purified B. alvei and B. cereus amylase was loaded into wells parallel 157 to the standard protein markers. The protein bands were stained with Coomassie brilliant blue 158 (Sigma, St. Louis, MO, USA). We estimated the enzyme's relative molecular weight by 159 comparing it to molecular mass standard markers (Fermentas, Vilnius, Lithuania).

\section{7- Antibacterial activities}

161

162

163

164

165

166

167

168

169

170

171

172

7.1. Antagonistic efficacy of the isolated bacteria. We compared the antagonistic efficacy of all isolates against five human pathogenic strains (Escherichia coli, P. aeruginosa, S. aureus (MRSA), Klebsiella pneumoniae, and Acinetobacter baumanii). Strains were kindly provided by the International Luxor Hospital in Luxor Governorate, Egypt. We performed screening using the disc diffusion method. All bacteria were cultured on TSB modified with 1\% starch, adjusted to $\mathrm{OD}_{595}=0.01$, and incubated at $37^{\circ} \mathrm{C}$ at $24 \mathrm{~h}$. The isolated bacterial cultures were centrifuged to exclude the cell debris (6,000 rm for 15 min., Biofuge). We then modified $20 \mathrm{ml}$ of TSA with $1 \%$ starch, and poured it in a sterile Petri plate (100 mm diameter). We streaked $100 \mu 1$ of the five tested pathogens on the plates and punched 6-mm wells in the plates using a sterile borer. The wells were then filled with $100 \mu 1$ of the isolated bacteria filtrate, and the plates were incubated at $37^{\circ} \mathrm{C}$ for $24 \mathrm{~h}$. The inhibition zone was measured using a ruler (Reinheimer et al., 1990). Standard antibiotics were used as the controls according to the Kirby Bauer disk diffusion 
173 method (Bauer et al., 1966). The antibiotics were chloramphenicol (C; $30 \mu \mathrm{g}$, Oxoid), oxacillin

174 (OX; $1 \mathrm{mcg}$, Bioanalyse ${ }^{\circledR}$ ), vancomycin (VA; $30 \mathrm{mcg}$, Bioanalyse ${ }^{\circledR}$ ), ampicillin/sulbactam

175 (SAM; 10/10 mcg, Bioanalyse $\left.{ }^{\circledR}\right)$, penicillin G (P; 10 U; Bioanalyse $\left.{ }^{\circledR}\right)$, erythromycin (E; 15

$176 \mathrm{mcg}$, Bioanalyse ${ }^{\circledR}$ ), sulfamethoxazole/trimethoprim (SXT; 23.75/1.25 $\mu \mathrm{g}$, BBL ${ }^{\mathrm{TM}}$ ), cefotaxime

177 (CTX; 30 mcg, Bioanalyse $\left.{ }^{\circledR}\right)$, gentamycin (GM; $10 \mu \mathrm{g}$, Bioanalyse $\left.{ }^{\circledR}\right)$, meropenem (MEM;

$17810 \mu \mathrm{g}$, Bioanalyse ${ }^{\circledR}$ ), piperacillin (PIP; $100 \mu \mathrm{g}$, Bioanalyse ${ }^{\circledR}$ ), and piperacillin-tazobactam (PTZ;

$179100 / 10 \mu \mathrm{g}$, Bioanalyse $\left.{ }^{\circledR}\right)$. We interpreted the results using the Clinical Laboratory Standard

180 Institute guidelines (CLSI, 2017) to determine whether the tested pathogens were resistant,

181 intermediate, or sensitive against the antibiotics.

182 7.2. Antibacterial activity of purified amylase enzyme from the isolated Bacillus. We placed

$183100 \mu 1$ of purified amylase from the selected isolates according to their SHR in the wells of the

184 agar plates inoculated with the target strains. The plates were incubated at $37^{\circ} \mathrm{C}$ for $24 \mathrm{~h}$. The

185 halo zone was measured using a ruler.

186 7.3. Biofilm formation assay. We determined the biofilm formation ability of the tested

187 pathogens (E. coli, P. aeruginosa, S. aureus (MRSA), K. pneumoniae, and A. baumanii) using

188 96-well polystyrene plates (Seper et al., 2011) and the methods described by Salem et al. (2015):

189 isolates were subcultured on tryptic soy agar for $24 \mathrm{~h}$ at $37^{\circ} \mathrm{C}$, suspended in tryptic soy broth, and

190 adjusted to an $\mathrm{OD}_{595}$ of 0.02 . We placed $130 \mu \mathrm{l}$ of each adjusted isolate culture in the microtitre

191 plate (U bottom, Sterilin) for 24 and $48 \mathrm{~h}$ at $37^{\circ} \mathrm{C}$. After incubation, the wells were washed with

192 distilled water (six times) and were stained with $0.1 \%$ crystal violet for $10 \mathrm{~min}$. The wells were

193 then washed again with distilled water (four times) to remove excess stain. Finally, the wells

194 were destained using $210 \mu \mathrm{l}$ of ethanol $96 \%$, and the $\mathrm{OD}_{595}$ was read using an Infinite ${ }^{\circledR}$ F50

195 Robotic (Ostrich) Microplate Plate to quantify the amount of biofilm. 
197 We compared the antibiofilm effects of the isolated bacteria filtrate and the purified amylase

198 from the selected isolates against the five human biofilm pathogenic bacteria using the following 199 spectrophotometric methods: a fresh isolate culture was prepared and adjusted to 0.5 McFarland $200\left(10^{6} \mathrm{CFU} / \mathrm{ml}\right)$, and $30 \mu \mathrm{l}$ (this volume was selected according to a preliminary experiment) of 201 these cultures and purified amylase enzyme were added to $130 \mu \mathrm{l}$ of the tested pathogens at an $202 \mathrm{OD}_{595}$ of 0.02 after $24 \mathrm{~h}$ of incubation at $37^{\circ} \mathrm{C}$ to allow biofilm formation. The plates were then 203 incubated for 24 and $48 \mathrm{~h}$ and stained with crystal violet. Wells without isolated cultures or 204 amylase served as controls.

205 Statistical analysis. The variability degree of the results was expressed in the form of mean \pm 206 standard deviation (mean $\pm \mathrm{SD}$ ) based on three independent determinations $(\mathrm{n}=3$ ). We 207 statistically analyzed the data by one-way ANOVA analysis and compared the control and 208 treatment groups using the least significant difference (LSD) test at 1\% (*) levels (Snedecor \& 209 Cochran, 1980).

210 Results and Discussion

211 1- Screening and isolating amylase-producing bacteria. Microorganisms that produce 212 amylase are generally isolated from soil and other sources (Fossi et al., 2005). Our study 213 explored the isolation of amylase-producing bacteria from soil using the serial dilution spread 214 plate technique. Singh \& Kumari (2016) used a similar method by diluting soil samples on starch 215 agar plates and flooding the plates with an iodine solution. The presence of a halo zone around 216 certain colonies indicated amylase production, and a total of 75 bacterial isolates showed a zone 217 of clearance with a starch agar medium. Bacterial isolates were selected according to their 218 amylolytic activity (Table 1). A similar method was also employed by Magalhaes (2010). We 219 further characterized isolates using morphological and biochemical tests shown in Tables 1 and 
220 2. Our results showed that the 75 isolates were comprised of 19 B. megaterium, 12 B. subtilis, 10

221 B. cereus, eight B. thuringiesis, eight B. lentus, four B. mycoides, four B. alvei, three $B$. 222 polymyxa, three $B$. circulans, and three Micrococcus roseus. B. megaterium had the highest 223 recorded prevalence (26.7\%) and B. circulans and Micrococcus roseus had the lowest (4\%). The 224 CFU of the amylase-producing bacteria in our 100 soil samples ranged from $115 \times 10^{3}-198 \times 10^{5}$ $225 \mathrm{CFU} / \mathrm{ml}$ (Table 1).

226 2- Optimizing amylase production. Using the starch hydrolysis rates shown in Table 2, we 227 selected the six isolates with the highest hydrolysis rates, namely B. alvei, B. thuringiesis, $B$. 228 megaterium, B. subtilis, B. cerus, and B. lentus with SHRs of 6.0, 5.67, 5.33, 5.0, 4.0, and 3.5 $229 \mathrm{~mm}$, respectively, for amylase purification.

a- Effect of temperature and time intervals. All isolates showed maximum amylase 231 production after $24 \mathrm{~h}$. Similar results were obtained by Singh \& Kumari (2016), who observed 232 that the highest amylase activity of some Bacillus sp. occurred at $24 \mathrm{~h}$ of incubation and that the activity began to decrease after 48 and $72 \mathrm{~h}$ of incubation time (Fig. 1B). B. megaterium, $B$. 234 subtilis, and $B$. cereus showed maximum amylase production at $45^{\circ} \mathrm{C}$, while other isolates showed maximum amylase production at $55^{\circ} \mathrm{C}$. Mohamed et al. (2009) similarly reported that some amylase were stable at $40^{\circ} \mathrm{C}$ and some at $50^{\circ} \mathrm{C}$ (Fig. 1A).

b- Effect of pH. All Bacillus isolates showed maximum amylase production at a $\mathrm{pH}$ of 8, except for B. subtilis which maximally produced amylase at a $\mathrm{pH}$ of 7. A previous study by Behal et al. (2006) found that the optimum $\mathrm{pH}$ for amylase production was 8 . Another study by Singh \& 10, maximum activity was observed at pH 7 (Fig. 1C). 
242 c- Effect of substrate concentration. Our results showed that B. subtilis and B. cereus had 243 maximum amylase production at 1.5\% soluble starch concentration. The remaining isolates 244 showed maximum amylase production at $2.0 \%$ soluble starch concetration (Fig. 1D). Mishra \& 245 Behera (2008) reported that Bacillus strains produced the maximum yield of amylase at a starch 246 concentration of $2 \%$.

247 d- Enzyme activity. We purified extracellular amylase from the Bacillus isolated from soil to 248 homogeneity using 45-85\% ammonium sulfate precipitation and Sephadex G-200 (Fig. 2). As 249 shown in Table 3, the highest amylase activity was found in B. alvei $(96.02 \mathrm{U} / \mathrm{ml})$, followed by 250 B. thuringiesis $(88.64 \mathrm{U} / \mathrm{ml})$. B. megaterium, B. subtilis, and B. cereus showed amylase activities 251 of $80.03,76.0$, and $55.9 \mathrm{U} / \mathrm{ml}$, respectively. B. lentus showed the lowest amylase activity of $25245.69 \mathrm{U} / \mathrm{ml}$.

253 e- SDS-PAGE. After purification, the SDS- PAGE profile showed a single protein band of 254 amylase for each bacteria, confirming that the enzyme has been purified to homogeneity. The 255 molecular weights of B. alvei and B. cereus were $60 \mathrm{KDa}$ and $43 \mathrm{KDa}$, respectively (Fig. 3). The 256 molecular weight of $B$. alvei was similar to that of the amylase isolated from B. subtilis (56 KDa 257 and $55 \mathrm{KDa}$, respectively) (Bano et al., 2011; Takkinen et al., 1983). The molecular weight of $B$. 258 cereus was equal to the molecular weight of amylase from B. cereus and B. subtilis (42 KDa) 259 (Annamalai et al., 2011; Das et al., 2004). Previous studies have reported different molecular 260 weights for amylase isolated from Bacillus sp. Lin et al. (1998) found that Bacillus sp. can 261 produce five different forms of amylase.

\section{3- Antibacterial activity}

263 3.1. Antagonistic efficacy of the isolated bacteria and purified amylase enzyme from 264 selected isolates. In this study, we compared the antimicrobial activity of Bacillus supernatant 
265 and purified amylase with standard antibiotics against human pathogens (Table 4). The standard 266 antibiotics served as the control group since pathogenic bacteria can become extremely resistant 267 to widely-used antibiotics. The pharmaceutical industry is in need of new and natural 268 antimicrobials that can overcome the problem of multidrug-resistant strains (Schmidt, 2004; 269 Salem et al., 2015; 2017). Several soil organisms can produce antibiotics using a survival 270 mechanism that can eliminate their competition (Talaro \& Talaro, 1996; Jensen \& Wright, 271 1997). The Bacillus genus is a terrestrial strain that can produce inhibitory compounds from 272 peptide-derivative and lipopolypeptide antibiotics (Mannanov \& Sattarova, 2001; Tamehiro et 273 al., 2002; Stein, 2005). Oscaiz et al. (1999) and Yilmaz et al. (2006) found that isolated 274 bacteriocin-producing strains such as Bacillus sp. were active against gram-negative and gram275 positive bacteria. We compared the antimicrobial activity of the isolated amylase-producing 276 bacteria and purified amylase against five human pathogenic bacteria (Table 4). We found that $E$. 277 coli was resistant to sulfamethoxazole-trimethoprim $(23.75 / 1.25 \mathrm{mcg})$, gentamycin $(10 \mu \mathrm{g})$, 278 cefotaxime $(30 \mu \mathrm{g})$, piperacillin $(100 \mu \mathrm{g})$, and piperacillin-tazobactam $(100 / 10 \mu \mathrm{g})$; showed 279 intermediate sensitivity to ampicillin-sulbactam $(10 / 10 \mathrm{mcg})$; and was sensitive to 280 chloramphenicol $(30 \mu \mathrm{g})$ and meropenem $(10 \mu \mathrm{g})$. Notably, we observed that all isolated bacteria 281 showed high antimicrobial activity in response to E. coli, with B. polymyxa showing the most 282 activity $(36 \mathrm{~mm})$ and $B$. subtilis and $B$. cereus showing the least $(12 \mathrm{~mm})$. B. mycoides and $M$. 283 roseus showed no antimicrobial activity in response to E. coli. Our results were consistent with 284 the results of Moshafi et al. (2011), who observed that one soil bacterial isolate, identified as 285 Bacillus sp., was found to inhibit six pathogenic bacteria, namely E. coli, K. pneumoniae, S. 286 typhi, P. aeruginosa, S. aureus, and S. epidermidis. When examining the antimicrobial activity in 287 response to $K$. pneumoniae, we found that although $K$. pneumoniae was resistant to all tested 
288 antibiotics, it showed intermediate sensitivity to ampicillin-sulbactam $(10 / 10 \mathrm{mcg})$. It is worth 289 mentioning that all isolates had great antimicrobial effects, with B. megaterium showing the 290 highest inhibition $(26 \mathrm{~mm})$ and B. polymyxa showing the lowest $(17 \mathrm{~mm})$ (Table 4). In contrast, 291 B. mycoides and M. roseus were resistant to K. pneumoniae. In a recent study, Ozabor \& 292 Fadahunsi (2019) reported that B. subtilis metabolites inhibited K. pneumoniae, P. aeruginosa, 293 S. aureus, E. coli, P. mirabilis, and other bacteria. A. baumanii was resistant to all tested 294 antibiotics and was sensitive only to chloramphenicol $(30 \mu \mathrm{g})$. However, all isolated bacteria 295 showed improved antibacterial effects against the tested pathogens, with B. alvei and B. cirulans 296 showing the greatest inhibitory effects $(39 \mathrm{~mm})$, and $B$. subtilis and $B$. thuringiesis showing the 297 lowest $(21 \mathrm{~mm})$ (Table 4). We found that B. mycoides and Micrococcus roseus displayed no 298 inhibitory effects against the tested pathogens. Ramachandran et al. (2014) reported that $B$. 299 subtilis showed antimicrobial activity against A. baumanii, E. coli, K. pneumoniae, P. 300 aeruginosa, and $S$. aureus. The susceptibility level of $P$. aeruginosa indicated that it was 301 resistant to sulfamethoxazole-trimethoprim $(23.75 / 1.25 \mu \mathrm{g})$, cefotaxime $(30 \mathrm{mcg})$, gentamycin $302(10 \mu \mathrm{g})$, meropenem $(10 \mu \mathrm{g})$, and piperacillin $(100 \mu \mathrm{g})$. It had intermediate sensitivity to 303 chloramphenicol $(30 \mu \mathrm{g})$ and ampicillin-sulbactam $(10 / 10 \mathrm{mcg})$, and was sensitive to 304 piperacillin-tazobactam $(100 / 10 \mu \mathrm{g})$. We noted that all isolates showed great antibacterial effects 305 against the tested pathogens, with B. lentus and B. cirulans having the greatest effects $(32 \mathrm{~mm})$ 306 and B. subtilis having the least $(15 \mathrm{~mm})$. Salem et al. (2015) similarly reported that Bacillus 307 strains exhibited antimicrobial activity against P. aeruginosa, E. coli, and S. typhi. Perez et al. 308 (1992) and Aslim et al. (2002) found that B. subtilis, B. thuringiesis, and B. megaterium showed 309 antibacterial activity against $E$. coli and P. aeruginosa. We found that $S$. aureus (MRSA) was 310 resistant to oxacillin ( $1 \mathrm{mcg})$, vancomycin $(30 \mathrm{mcg})$, penicillin $\mathrm{G}(10 \mathrm{U})$, cefotaxime (30 $\mathrm{mcg})$, 
311 and gentamycin $(10 \mu \mathrm{g})$, and showed intermediate sensitivity to chloramphenicol $(30 \mu \mathrm{g})$,

312 erythromycin (15 mcg), and sulfamethoxazole-trimethoprim (23.75/1.25 $\mu \mathrm{g})$. The isolated

313 amylase-producing bacteria showed better antibacterial effects on the tested pathogens, with the

314 greatest effect shown by $B$. alvei $(48 \mathrm{~mm})$ and the least effect shown by $B$. cereus $(14 \mathrm{~mm})$

315 (Table 4). However, B. mycoides and M. roseus did not affect S. aureus. Similar results were

316 obtained by Moshafi et al. (2011) and Ramachandran et al. (2014). In contrast to the high

317 antimicrobial activity observed in the isolated soil bacteria, the purified amylase from the

318 selected isolates had very little effect on $E$. coli and $K$. pneumoniae (the highest inhibition

319 diameter was $7.5 \mathrm{~mm}$ ), and no recorded effect in response to the other tested pathogens (Table

320 4). This result is similar to that of Kalpana et al, (2012), who confirmed that amylase enzyme

321 has no antibacterial effect.

322 3.2. Biofilm formation assay. We quantitatively determined the amount of biofilm $\left(\mathrm{OD}_{595}\right)$ in

323 the tested pathogens and designated the 24 and $48 \mathrm{~h}$ treatments as the control groups (Figs. 4, 5,

324 6, and 7). Using the $\mathrm{OD}_{595} \mathrm{~nm}$ mean values, we defined the pathogens as low, moderate, or high

325 bacterial biofilm formers when the $\mathrm{OD}_{595} \mathrm{~nm}$ was $<1,1-2.9$, and $>2.9$, respectively. $A$.

326 baumanii and Klebsiella pneumoniae were high biofilm formers while E. coli, P. aeruginosa,

327 and S. aureus (MRSA) were low biofilm formers.

328 3.3. Antibiofilm activity of isolated bacterial filtrate and purified amylase enzyme from

329 selected Bacillus isolates. In a natural ecosystem, bacteria can be exist in two forms: planktonic

330 cells, which are susceptible to antibiotics and other antimicrobial agents, and biofilm, which are

331 resistant to antibiotics and disinfectants (Limoli et al., 2015). A biofilm is a complex community

332 of bacteria attached to a surface or interface enclosed in an exopolysaccharide matrix, protected

333 from unfavorable antibiotics, host defenses, or oxidative stresses (Shakibaie, 2018). Microbial 
334 biofilms have created huge problems in the treatment of both community and hospital infections.

335 Most antimicrobial agents are unable to penetrate biofilm due to its extracellular polymeric

336 substances (EPS), which act as a barrier protecting the bacterial cells within the biofilm.

337 Therefore, we must use compounds that have the potential to degrade the biofilm's EPS.

338 Enzymes have proven to be effective in EPS degradation (Kalapna et al., 2012; Lequette et al.,

339 2010). In our study, we compared the antibiofilm activity of the Bacillus sp. that we isolated

340 from soil (supernatant) and the purified amylase from these isolates against five human

341 pathogenic biofilm former strains. Our study has reported that Bacillus supernatant and amylase

342 enzyme can inhibit the biofilm formation in various pathogens. We confirmed the ability of

343 pathogenic bacterial strains to form biofilm formation using spectrophotometric methods before

344 applying the antibiofilm treatments of bacterial filtrate and purified amylase enzyme (Fig. 4, 5, 6,

345 and 7). The antibiofilm activity was screened using a spectrophotometric method with crystal

346 violet staining. Our results showed that the bacteria isolated from soil exhibited significant

347 antibiolfilm effects against the tested pathogenic strains after $24 \mathrm{~h}$ of treatment. The percentage

348 of inhibition significantly increased after $48 \mathrm{~h}$ of treatment. The highest percentage of inhibition

349 was recorded for B. circulans against K. pneumonia: $93.7 \%$ after $48 \mathrm{~h}$ of treatment (Fig. 5D,

350 T8). We also monitored the efficacy of the purified amylase enzyme as an antibiofilm against the

351 same tested pathogens. Our results revealed that the purified amylase showed significant

352 antibiofilm effects after $24 \mathrm{~h}$ of treatment. The percentages of inhibition significantly increased

353 after $48 \mathrm{~h}$ of treatment. We observed the highest percentage for $B$. alvei against $K$. pneumonia:

$35478.8 \%$ after $48 \mathrm{~h}$ of treatment (Fig. 7D, T6). Our results also showed the greatest enzyme activity

355 from B. alvei $(96.02 \mathrm{U} / \mathrm{ml})$, followed by B. thuringiesis $(88.64 \mathrm{U} / \mathrm{ml})$, B. megaterium $(80.03 \mathrm{U} /$

$356 \mathrm{ml})$, and B. subtilis $(76.0 \mathrm{U} / \mathrm{ml})$. The lowest antibiofilm efficacy was recorded in B. cereus, with 
357 an enzyme activity of $55.9 \mathrm{U} / \mathrm{ml}$, and B. lentus, with an enzyme activity of $45.69 \mathrm{U} / \mathrm{ml}$. Kalpana

358 et al., (2012) first reported that purified amylase enzyme from B. subtilis was a good antibiofilm

359 agent against biofilm-forming clinical pathogens. The purified enzyme caused $68.33 \%, 64.84 \%$,

$36061.81 \%$, and $59.2 \%$ of inhibition in $V$. cholerae (VC5, VC26), MRSA (102), and P. aeruginosa

361 ATCC10145, respectively. Another study by Vaikundamoorthy et al., (2018) confirmed the

362 antibiofilm efficacy of the thermostable amylase enzyme from B. cereus.

363 It is worth noting that the isolated bacteria filtrate showed great antibiofilm activity compared to

364 the purified amylase enzyme from the selected isolates. This may be due to the accumulation of

365 some extracellular and intracellular metabolites in the medium, which is further explained by the

366 metabolic overflow theory (Pinu et al., 2017; Pinu et al., 2018; Horak et al., 2019). Bacillus also

367 showed great efficacy in the production of carbohydrate-active enzymes and bioactive

368 compounds, as well as the secretion of a variety of extracellular metabolites and lytic enzymes

369 (Abdel-Aziz, 2013). Additionally, Bacillus species are the most efficient at producing peptide

370 antibiotic compounds such as polymyxin, colistin, and circulin (Katz \& Domain, 1997;

371 Atanasova-Pancevska et al., 2016). Our results also indicated a great inhibition of biofilm from

372 the amylase enzymes of $B$. alvei $(96.02 \mathrm{U} / \mathrm{ml})$, followed by $B$. thuringiesis $(88.64 \mathrm{U} / \mathrm{ml}), B$.

373 megaterium $(80.03 \mathrm{U} / \mathrm{ml})$, B. subtilis $(76.0 \mathrm{U} / \mathrm{ml})$, B. cereus $(55.9 \mathrm{U} / \mathrm{ml})$, and B. lentus $(45.69$

$374 \mathrm{U} / \mathrm{ml}$ ) (Table 3). This may be due to the increased enzyme activity in each species.

\section{Conclusion}

376 Our results indicated that the ability of Bacillus $s p$. to produce extracellular and intracellular

377 metabolites, lytic enzymes, and some peptide antibiotics directly affects the antimicrobial

378 functions of various Bacillus sp. (amylase producers) in the soil. We observed the highest

379 inhibition rate (93.7\%) when comparing the species' antibiofilm effects against five human

380 pathogenic strains. We observed an inhibition rate of $78.8 \%$ when comparing the antibiotic 
381 biofilm activity of purified amylase against the strains. Our study showed that Bacillus filtrate is

382 an effective clinical antibiofilm. Futher studies are being conducted to determine the exact 383 composition of the filtrate and its active agents.

\section{References}

385 Abdel-Aziz, SM. 2013. Extracellular Metabolites Produced by a Novel Strain, Bacillus alvei 386 NRC-14: 5. Multiple Plant-Growth Promoting Properties. J Basic Appl Sci Res 3(1): 670-682.

387

388

389

390

391

392

393

394

395

396

397

398

399

400

401

402

403

Abd-Elhahlem BT, El-Saway M, Gamal RF, Abou-Taleb KA. 2015. Production of amylases from Bacillus amyloliquefaciens under submerged fermentation using some agro-industrial by-products. Ann Agr Sci 60(2): 193-202.

Annamalai N, Thavasi R, Vijayalakshmi S, Balasubramanian T. 2011. Extraction, Purification and Characterization of Thermostable, Alkaline Tolerant a-Amylase from Bacillus cereus. Indian J Microbiol 51(4):424-429.

Aslim B, Saglam N, Beyatli Y. 2002. Determination of some properties of Bacillus isolated from soil. Turk J Biol 26: 41-48.

Atanasova-Pancevska N, Popovska I, Davalieva K, Kungulovski D. 2016. Screening for Antimicrobial Activity of Bacillus subtilis and Paenibacillus Alvei Isolated From Rotten Apples Compost. Acta Microbiolo Bulg 57-64.

Bano S, UI Qader SA, Aman A, Syed MN, Azhar A. 2011. Purification and Characterization of Novel $\alpha$-Amylase from Bacillus subtilis KIBGE HAS. AAPS Pharm Sci Tech 12(1): 255-261.

Bauer KA, Sherris J, Turk M. 1966. Antibiotic susceptibility testing by standardized single disc method. Am J Clin Pathol 45: 493-496.

Behal A., Singh J., Sharma M.K., Puri P., Batra N. 2006. Studied thermostable amylase producing Bacillus sp. Int J Agri Boil. 8: 80-83. 
404 Bradford MM. 1976. A rapid and sensitive method for the quantition of microgram quantities of 405 protein -dye binding. Analy Biochem 72: 248-254.

406 Clinical and Laboratory Standards Institute (CLSI), Document M100 2017. Performance 407 Standards for Susceptibility Testing: $27^{\text {th }}$ ed., Clin Lab Stand Inst 37: 1- 282.

408 Collins C, Lyne P. 1984. Microbiological methods $5^{\text {th }}$ microbiology laboratory manual, British 409 Liberary. Butter Worth, Inc., United Kingdom.

410 Cruickshank R, Duguid J, Marmion B, Swain R. 1975. Medical Microbiology 12 ${ }^{\text {th }}$, ed., 411 Edinburg, London and New York.

412 Das K, Doley R, Mukherjee AK. 2004. Purification and biochemical characterization of a 413 thermostable, alkaliphilic, extracellular a-amylase from Bacillus subtilis DM-03, a strain 414 isolated from the traditional fermented food of India. Biotechnol Appl Biochem 40:291-298.

415 Dash BK, Rahman MM, Sarker PK. 2015. Molecular Identification of a Newly Isolated 416 Bacillus subtilis BI19 and Optimization of Production Conditions for Enhanced Production of 417 Extracellular Amylase. Bio Med Res Int 1-9.

418 de Carvalho, C. C. C. C. R. 2007. Biofilms: Recent developments on an old battle. Recent 419 Patents on Biotechnology. 1: 49-57.

Elamary RB, Albarakaty FM, Salem WM. 2020. Efficacy of Acacia nilotica aqueous extract in 421 treating biofilm-forming and multidrug resistant uropathogens isolated from patients with UTI syndrome. Scientific Reports, 10(1): 1-14.

El-Fallal A, Dobara MA, El-Sayed A, Omar N. 2012. Starch and Microbial á-Amylases: From 424 Concepts to Biotechnological Applications. In Chang, Carbohydrates - Comprehensive 425 Studies on Glycobiol Glycotechnol 459-476. 
426 Fossi BT, Taveaand F, Ndjonenkeu T, 2005. Production and partial characterization of a 427 themostable amylase from ascomycetes yeast strain isolated from starchy soils. Afr $J$ $428 \quad$ Biotechnol. 4: 14-18

429 Gupta R, Gigras P, Mohapatra H, Goswami VK, Chauhan B. 2003. Microbial-amylases: A 430 Biotechnological perspective. Process Biochem. 38: 1599-1616.

431 Hall-Stoodley L, Costerton JW, Stoodley P. 2004. Bacterial biofilms: from the natural 432 environment to infectious diseases. Nature Revie Microbiol 2: 95-108.

Horak G, Engelbrecht PJ, Rensburg JV, Claassens S. 2019. Microbial metabolomics: essential definitions and the importance of cultivation conditions for utilizing Bacillus species as bionematicides. Journal of Applied Microbiology. 127: 326-343.

Islam T, Choudury N, Hossain MM, Khan TT. 2017. Isolation of Amylase Producing Bacteria from Soil, Identification by $16 \mathrm{~S}$ rRNA Gene Sequencing and Characterization of Amylase. Bangladesh J Microbiol 34 (1): 01-06.

Jamil B, Hasan F, Hameed A, Ahmed S. 2007. Isolation of Bacillus subtilis MH-4 from Soil and its Potential of Polypeptidic Antibiotic Production. Pak J Pharm Sci 20(1): 26-31.

Jensen MJ, Wright DN. 1997. Chemotherapeutic Agents. In: Microbiology for the Health Sciences: Prentice Hall, New York 132-145.

Kalpana BJ, Aarthy S, Pandian SK. 2012. Antibiofilm Activity of $\alpha$-Amylase from Bacillus subtilis S8-18 Against Biofilm Forming Human Bacterial Pathogens. Appl Biochem Biotechnol 167: 1778-1794.

Katz E, Demain AL. 1997. The peptide antibiotics of Bacillus, chemistry, biogenesis, and possible functions. Bacteriol Rev 41: 449-474. 
448 Kaur A, Kaur M, Samyal ML, Ahmed Z. 2012. Isolation, characterization and identification of 449 bacterial strain producing amylase. J Microbiol Biotech Res 2 (4): 573-579.

450 Koneman E, Allen S, JandaW, Schrenchen P, Winn W. 1992. Color atlas and Text book of 451 Diagnostic Microbiolog. $4^{\text {th }}$ Ed. Published by L.B Lippincott Company, Philadelphia, USA.

452 453 454

Laemmli UK. 1970. Cleavage of structural proteins during the assembly of the head of bacteriophage T4. Nature 227:680-685.

Lequette Y, Boelsb G, Clarissea M, Faille C. 2010. Using enzymes to remove biofilms of bacterial isolates sampled in the food-industry. Biofouling 26: 421-431.

Limoli DH, Jones CJ, Wozniak DJ. 2015. Bacterial extracellular polysaccharides in biofilm formation and function. Microbiol Spectr 3: 10.

Lin LL, Chyau CC, Hsu WH. 1998. Production and properties of a raw-starch-degrading amylase from the thermophilic and alkaliphilic Bacillus sp. TS-23. Biotechnol Appl Biochem 28:61-68.

Magalhaes. 2010. Application of microbial alpha amylase in industry. Braz J Microbiol. 41(4), Sao Paulo Oct/Dec,

Mannanov RN, Sattarova RK. 2001. Antibiotics produced by Bacillus bacteria. Chem Nat Comp. 37: 117-123.

Meyer KH, Fisher EH, Bernfeld P. 1951. In: " General Biochemistry". Fritton, S. S. and Simmods, S. (eds.) (1951). 2nd. ed. pp. 434-450. J. Wiley, New York.

Mohamed SA, Malki AL, Kumosani TA 2009. Studied effect of temperature on amylase production by Bacillus sp. Australian J Basic Appl Sci. 3:1740-1748. 
469

470

471

472

473

474

475

476

477

478

479

480

481

482

483

484

485

486

487

488

489

490

491

Moshafi MH, Forootanfar H, Ameri A, Shakibaie M, Dehghan-Noudeh G, Razavi M. 2011. Antimicrobial Activity of Bacillus Sp. Strain Fas1 Isolated From Soil. Pak J Pharm Sci. 24(3): 269-275.

Nimisha P, Moksha S, Gangawane AK. 2019. Amylase Activity of Starch Degrading Bacteria Isolated from Soil. Int J Curr Microbiol App Sci 8(4): 659-671.

Oscariz JC, Lasa I, Pisabarro AG. 1999. Detection and characterization of cerein 7, a new bacteriocin produced by Bacillus cereus with a broad spectrum of activity. FEMS Microbiol Lett 178: 337-341.

Ozabor TP, Fadahunsi, IF. 2019. Antimicrobial Activity of Bacillus Subtilis Against Some Selected Food Borne Pathogens. Acta Scientific Microbiology 2 (7): 89-95.

Perez C, Suarez C, Castro GR. 1992. Production of antimicrobials by Bacillus subtilis MIR 15. J Biotechnol 26: 331-336.

Perez C, Suarez C, Castro GR. 1993. Antimicrobial activity determined in strains of Bacillus circulans cluster. Folia Microbiol 38 (1): 25-28.

Pinu FR, Granucci N, Daniell J, Han TL, Carneiro S, Rocha I, Nielsen J, Villas-Boas SG. 2018. Metabolite secretion in microorganisms: the theory of metabolic overflow put to the test. Metabolomics 14: 43.

Pinu FR, Villas-Boas SG, Aggio R. 2017. Analysis of intracellular metabolites from microorganisms: quenching and extraction protocols. Metabolites 7(4): 53.

Prakash B, Veeregowda BM, Krishnappa G. 2003. Biofilms: A survival strategy of bacteria. Cur Sci 85: 9-10.

Pranay K, Padmadeo SR, Jha V, Prasadss B. 2019. Screening and identification of amylase producing strains of Bacillus. Journal of Applied Biolo Biotechnol 1-6. 
492 Ramachandran R, Chalasani AG, Lal, R., Roy U. 2014. A Broad-Spectrum antimicrobial 493 Activity of Bacillus subtilis RLID 12.1. The ScientificWorld Journal. Article ID 968487. 1$494 \quad 10$.

495 Rasooli I, Astaneh SDA, Borna H, Barchini KAA. 2008. Thermostable a-Amylase Producing 496 Natural Variant of Bacillus spp. Isolated From Soil in Iran. American Journal of Agricultural $497 \quad$ and Biological Sciences 3 (3): 591-96.

498 Reed JF, Rigney JA. 1947. Soil sampling from fields of uniform and nonuniform appearance $499 \quad$ and soil types. J Ame Soc Agr 39: 26-40.

500 Reinheimer JA, Demkov MR, Condioti MC. 1990. Inhibition of coliform bacteria by lactic 501 cultures. Aust. J. Dairy Technol. May 5-9.

502 Rodrigues WF, Miguel CB, Nogueira APO, Ueira-Vieira C, Paulino, TDP, Soares, SDC, De 503 504 505 Study. Int J Environ Res Public Health 13, p 918

Roe S. 2001. Purification and Concentration by Precipitation. New York, NY, USA: Oxford 507 University Press (S. Roe, Ed.).

Saber H, Alwaleed EA, Ebnalwaled KA, Sayed A, Salem W. 2017. Efficacy of silver nanoparticles mediated by Jania rubens and Sargassum dentifolium macroalgae; Characterization and biomedical applications. Egyp. J. basic and appli. Sci. 4(4): 249-255.

Salem SH, El-Sheikh HH, Naguib MM, Heikal, YA. 2015. Potential antimicrobial activity of 512 the antagonistic Bacillus strains to Saccharomyces cerevisiae. JIPBS 2 (4): 632-645. 
513 Salem WM, El-Hamed DS, Sayed W, Elamary R. 2017. Alterations in virulence and antibiotic 514 resistant genes of multidrug-resistant Salmonella serovars isolated from poultry: The 515 bactericidal efficacy of Allium sativum. Microbial Pathogenesis, 108: 91-100.

516 Salem WM, Schneditz G, Dornisch E, Schild S. 2015. In vitro effects on biofilm viability, 517 cytotoxicity, and antibacterial activity of green $\mathrm{Ag}$ and $\mathrm{ZnO}$ nanoparticles against 518 Nontypeable Haemophilus influenza strains. JEAAS 1: 369-383.

519 Schmidt FR. 2004. The challenge of multidrug resistance: actual strategies in the development of 520 novel antibacterials 63 (4): 335-343.

521 Seper A, Fengler VH, Roier S, Wolinski H, Kohlwein SD, Bishop AL, Camilli A, Reidl J, 522 Schild S. 2011. Extracellular nucleases and extracellular DNA play important roles in Vibrio $523 \quad$ cholerae biofilm formation. Mol Microbiol 82: 1015-1037.

524 Shakibaie MR. 2018. Bacterial Biofilm and its Clinical Implications. Ann Microbiol Res $5252(1): 45-50$.

526

527

Sharma D, Misba L, Khan AU. 2019. Antibiotics versus biofilm: an emerging battleground in 528 microbial communities. Antimicrobial Resistance and Infection Control 8:76.

Shinde S, Soni R. 2014. Production and partial purification of $\alpha$-amylase from bacterial strains. 529 International Journal of Genetic Engine Biotechnolo 974(1): 57-62.

Singh, P. Kumari, P. 2016. Isolation and characterization of amylase producing Bacillus spp. 531 from selected soil sample. Int. J. Res. Biosciences 5(2): 24-29.

532 Snedeco GW, Cochran WG. 1980. Statistical Methods. 7th Edition, Iowa State University 533 Press, Ames.

534 Stein T. 2005. Bacillus subtilis antibiotics: structures, syntheses and specific functions. Mol 535 Microbiol 56: 845-857. 
536

537

538

539

540

541

542

543

544

545

546

547

548

549

550

551

552

553

Takkinen K, Pettersson RF, Kalkkinen N, Palva I, Söderlund H, Kääriäinen L. 1983. Amino acid sequence of alpha-amylase from Bacillus amyloliquefaciens deduced from the nucleotide sequence of the cloned gene. J Biol Chem. 258:1007-13.

Talaro A, Talaro K. 1996. Drugs, Microbes, Host. The Elements of Chemotherapy In Foundations in Microbiology. W.M. Brown: New York.

Tamehiro N, Okamoto-Hosoya Y, Okamoto S, Ubukata M, Masa HM, Naganawa H, Ochi K. 2002. Bacilysocin, a novel phospholipid antibiotic produced by Bacillus subtilis 168 . Antimicrob Agents Chemother 46: 315-320.

Vaikundamoorthya R, Rajendrana R, Selvaraju A, Moorthy K, Perumal S. 2018. Development of thermostable amylase enzyme from Bacillus cereus for potential antibiofilm activity. Bioorganic Chemistry 77: 494-506

Xavier JB, Picioreanu C, Rani SA, van Loosdrecht MCM, Stewart PS. 2005. Biofilm control strategies based on enzymatic disruption of the extracellular polymeric substance matrix- a modeling study. Microbiol 51: 3817-3832.

Yilmaza M, Sorana H, Beyatlib Y. 2006. Antimicrobial activities of some Bacillus spp. strains isolated from the soil. Microbiological Research 161: 127- 131.

Peer] reviewing PDF | (2020:03:46812:3:1:NEW 17 Sep 2020) 


\section{Table $\mathbf{1}$ (on next page)}

Prevalence of Bacillus species isolated from soil.

a: The amylase-producing bacteria isolated from soil. b: Number of each isolated type from the total number of the positive isolated sample, c: Percentage of each isolate, $d$ : Average colony-forming unit of amylase-producing bacteria per $\mathrm{ml}$ of $100 \mathrm{~g}$ soil samples (highest value to lowest value). 
Table (1): Prevalence of Bacillus species isolated from soil.

\begin{tabular}{|c|c|c|c|}
\hline Isolates $^{\mathbf{a}}$ & No. of isolates ${ }^{b}$ & Percentage $^{\mathbf{c}}(\%)$ & $\mathrm{CFUml}^{-1 \mathbf{d}}$ \\
\hline Bacillus megaterium & 20 & 26.7 & \\
\hline Bacillus subtilis & 12 & 16 & \\
\hline Bacillus cereus & 10 & 13.3 & 0 \\
\hline Bacillus thuringiesis & 8 & 10.7 & $\infty_{\infty}^{\infty}$ \\
\hline Bacillus lentus & 8 & 10.7 & 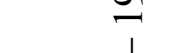 \\
\hline Bacillus mycoides & 4 & 5.3 & $m^{1}$ \\
\hline Bacillus alvei & 4 & 5.3 & $=$ \\
\hline Bacillus polymyxa & 3 & 4 & $\hat{n}$ \\
\hline Bacillus circulans & 3 & 4 & \\
\hline Micrococcus roseus & 3 & 4 & \\
\hline Total & 75 & 100 & \\
\hline
\end{tabular}

a: The amylase-producing bacteria isolated from soil. b: Number of each isolated type from the 4 total number of the positive isolated sample, c: Percentage of each isolate, d: Average colony- 5 forming unit of amylase-producing bacteria per $\mathrm{ml}$ of $100 \mathrm{~g}$ soil samples (highest value to lowest 6 value). 


\section{Table 2 (on next page)}

Biochemical activities of amylase-producing bacterial isolates and their starch hydrolysis rates.

a: Morphological and biochemical tests used for identifying isolated bacteria. +: Positive, -: Negative, b: starch hydrolysis rate. 
Table (2): Biochemical activities of amylase-producing bacterial isolates and their starch hydrolysis rates.

\begin{tabular}{|c|c|c|c|c|c|c|c|c|c|c|}
\hline Tests $^{\mathbf{a}}$ & $\begin{array}{c}\text { Gram } \\
\text { reaction }\end{array}$ & Motility & Catalase & $\begin{array}{l}\text { Egg yolk } \\
\text { lecithinase }\end{array}$ & $\begin{array}{l}\text { Nitrate } \\
\text { reduction }\end{array}$ & $\begin{array}{c}\text { Vogas } \\
\text { proskauer }\end{array}$ & $\begin{array}{c}\text { Citrate } \\
\text { utilization }\end{array}$ & $\begin{array}{c}\text { Gelatin } \\
\text { hydrolysis }\end{array}$ & $\begin{array}{c}\text { Starch } \\
\text { hydrolysis }\end{array}$ & $\begin{array}{c}\text { Indole } \\
\text { production }\end{array}$ \\
\hline Bacillus megaterium & + & + & + & - & - & - & + & + & + & - \\
\hline Bacillus cereus & + & + & + & + & + & + & + & - & + & - \\
\hline Bacillus thuringiesis & + & + & + & + & - & + & + & - & + & - \\
\hline Bacillus lentus & + & + & + & - & - & - & - & + & + & - \\
\hline Bacillus mycoides & + & - & + & + & - & + & + & - & + & + \\
\hline Bacillus alvei & + & + & + & - & - & + & - & + & + & + \\
\hline Bacillus polymyxa & + & + & + & - & + & + & - & + & + & - \\
\hline Bacillus circulans & + & + & + & - & + & - & - & + & + & - \\
\hline Micrococcus roseus & + & + & + & - & + & - & + & - & + & - \\
\hline & \multicolumn{10}{|c|}{ Starch hydrolysis rate $(\mathrm{mm})^{\mathbf{b}}$} \\
\hline & \multicolumn{4}{|c|}{ Halo zone $(\mathrm{mm})$} & \multicolumn{3}{|c|}{ Diameter of colony (mm) } & \multicolumn{3}{|c|}{ SHR } \\
\hline Bacillus megaterium & \multicolumn{4}{|c|}{16} & \multicolumn{3}{|c|}{3} & \multicolumn{3}{|c|}{5.33} \\
\hline Bacillus subtilis & \multicolumn{4}{|c|}{10} & \multicolumn{3}{|c|}{2} & \multicolumn{3}{|c|}{5.0} \\
\hline Bacillus thuringiesis & \multicolumn{4}{|c|}{17} & \multicolumn{3}{|c|}{3} & \multicolumn{3}{|c|}{5.67} \\
\hline Bacillus lentus & \multicolumn{4}{|c|}{14} & \multicolumn{3}{|c|}{4} & \multicolumn{3}{|c|}{3.5} \\
\hline Bacillus mycoides & \multicolumn{4}{|c|}{4} & \multicolumn{3}{|c|}{2} & \multicolumn{3}{|c|}{2.0} \\
\hline Bacillus alvei & \multicolumn{4}{|c|}{18} & \multicolumn{3}{|c|}{3} & \multicolumn{3}{|c|}{6.0} \\
\hline Bacillus polymyxa & \multicolumn{4}{|c|}{7} & \multicolumn{3}{|c|}{5} & \multicolumn{3}{|c|}{1.4} \\
\hline Bacillus circulans & \multicolumn{4}{|c|}{16} & \multicolumn{3}{|c|}{5} & \multicolumn{3}{|c|}{3.2} \\
\hline Micrococcus roseus & \multicolumn{4}{|c|}{10} & & 5 & & & 2.0 & \\
\hline
\end{tabular}




\section{Table 3(on next page)}

Purification profile of amylase produced from different Bacillus sp. isolates

a: Isolated Bacillus sp. selected for amylase purification according to SHR, b: Different purification steps of amylase purification, TP: total protein, TA: total activity, EA: enzyme activity. 
Table (3): Purification profile of amylase produced from different Bacillus sp. isolates

\begin{tabular}{|c|c|c|c|c|c|c|c|}
\hline Purification & $\begin{array}{l}\text { Isolates }^{\mathrm{a}} \\
\text { step }^{6}\end{array}$ & $\begin{array}{c}\text { Bacillus } \\
\text { megaterium }\end{array}$ & $\begin{array}{l}\text { Bacillus } \\
\text { subtilis }\end{array}$ & $\begin{array}{c}\text { Bacillus } \\
\text { cereus }\end{array}$ & $\begin{array}{c}\text { Bacillus } \\
\text { thuringiesis }\end{array}$ & $\begin{array}{c}\text { Bacillus } \\
\text { lentus }\end{array}$ & $\begin{array}{c}\text { Bacillus } \\
\text { alvei }\end{array}$ \\
\hline \multirow{3}{*}{ Crude } & $\mathrm{TP}(\mathrm{mg} / \mathrm{ml})$ & 0.66 & 0.96 & 0.81 & 0.54 & 0.99 & 0.86 \\
\hline & $\mathrm{TA}(\mathrm{U})$ & 6630 & 5000 & 3932 & 7890 & 2780 & 10040 \\
\hline & $\mathrm{EA}(\mathrm{U} / \mathrm{ml})$ & 33.15 & 25.0 & 19.66 & 39.45 & 13.9 & 50.2 \\
\hline \multirow{3}{*}{$\begin{array}{l}\text { Ammonium } \\
\text { sulfate }\end{array}$} & $\mathrm{TP}(\mathrm{mg} / \mathrm{ml})$ & 0.58 & 0.88 & 0.75 & 0.39 & 0.79 & 0.77 \\
\hline & TA(U) & 701.0 & 640 & 461.0 & 820 & 308 & 1029 \\
\hline & $\mathrm{EA}(\mathrm{U} / \mathrm{ml})$ & 35.06 & 32.0 & 23.08 & 41.0 & 15.4 & 51.47 \\
\hline \multirow{3}{*}{ Dialysis } & $\mathrm{TP}(\mathrm{mg} / \mathrm{ml})$ & 0.50 & 0.82 & 0.71 & 0.37 & 0.60 & 0.70 \\
\hline & $\mathrm{TA}(\mathrm{U})$ & 718 & 700 & 502 & 805 & 365 & 591 \\
\hline & $\mathrm{EA}(\mathrm{U} / \mathrm{ml})$ & 35.9 & 35.0 & 25.12 & 40.26 & 18.26 & 29.56 \\
\hline \multirow{3}{*}{$\begin{array}{l}\text { Sephadex G- } \\
200\end{array}$} & $\mathrm{TP}(\mathrm{mg} / \mathrm{ml})$ & 0.45 & 0.76 & 0.64 & 0.29 & 0.48 & 0.59 \\
\hline & $\mathrm{TA}(\mathrm{U})$ & 800 & 760 & 559 & 886 & 456.9 & 960 \\
\hline & $\mathrm{EA}(\mathrm{U} / \mathrm{ml})$ & 80.03 & 76.0 & 55.9 & 88.64 & 45.69 & 96.02 \\
\hline
\end{tabular}

a: Isolated Bacillus sp. selected for amylase purification according to SHR, b: Different 4 purification steps of amylase purification, TP: total protein, TA: total activity, EA: enzyme 5 activity. 


\section{Table 4 (on next page)}

Comparing the antibacterial activity of Bacillus sp. and purified amylase enzyme to different standard antibiotics.

a: Comparing the antimicrobial susceptibility of a group of standard antibiotics (CLSI, 2017) against five human pathogenic strains (control). $R=$ Resistant, $S=$ sensitive, $I=$ intermediate, $N A=$ Not applicable (for antibiotics that were not specific to the bacterial strains), b: antimicrobial activity of the isolated Bacillus sp., $\mathrm{NI}=$ No inhibition, $\mathrm{c}$ : antimicrobial activity of purified amylase from some isolated Bacillus sp., ABM = amylase purified from Bacillus megaterium, $A B S$ amylase purified from Bacillus subtilis, $A B C=$ amylase purified from purified Bacillus cereus, $A B T=$ amylase purified from Bacillus thuringiesis, $A B L=$ amylase purified from Bacillus lentus, $A B A=$ amylase purified from Bacillus alvei. Values expressed as mean \pm SD. 
Table (4): Comparing the antibacterial activity of Bacillus sp. and purified amylase enzyme to different standard antibiotics.

\begin{tabular}{|c|c|c|c|c|c|}
\hline Tested pathogens & $\begin{array}{c}\text { Escherichia } \\
\text { coli }\end{array}$ & $\begin{array}{c}\text { Klebsiella } \\
\text { pneumoniae }\end{array}$ & $\begin{array}{c}\text { Acinetobacter } \\
\text { baumanii }\end{array}$ & $\begin{array}{c}\text { Pseudomonas } \\
\text { aeuroginosa }\end{array}$ & $\begin{array}{c}\text { Staphylococcus } \\
\text { aureus (MRSA) }\end{array}$ \\
\hline Chloramphenicol $(30 \mu \mathrm{g})$ & $\mathrm{S}$ & $\mathrm{R}$ & $\mathrm{S}$ & I & I \\
\hline Oxacillin (1 mcg) & NA & NA & NA & NA & $\mathrm{R}$ \\
\hline Vancomycin $(30 \mathrm{mcg})$ & NA & NA & NA & NA & $\mathrm{R}$ \\
\hline Ampicillin- sulbactam $(10 / 10 \mathrm{mcg})$ & I & I & $\mathrm{R}$ & I & NA \\
\hline Pencillin G (10 U) & NA & NA & NA & NA & $\mathrm{R}$ \\
\hline Erythromycin $(15 \mathrm{mcg})$ & NA & NA & NA & NA & I \\
\hline Sulfameth.-trimethoprim $(23.75 / 1.25 \mu \mathrm{g})$ & $\mathrm{R}$ & $\mathrm{R}$ & $\mathrm{R}$ & $\mathrm{R}$ & I \\
\hline Cefotaxime $(30 \mathrm{mcg})$ & $\mathrm{R}$ & $\mathrm{R}$ & $\mathrm{R}$ & $\mathrm{R}$ & $\mathrm{R}$ \\
\hline Gentamycin $(10 \mu \mathrm{g})$ & $\mathrm{R}$ & $\mathrm{R}$ & $\mathrm{R}$ & $\mathrm{R}$ & $\mathrm{R}$ \\
\hline Meropenem $(10 \mu \mathrm{g})$ & $\mathrm{S}$ & $\mathrm{R}$ & $\mathrm{R}$ & $\mathrm{R}$ & NA \\
\hline Piperacillin $(100 \mu \mathrm{g})$ & $\mathrm{R}$ & $\mathrm{R}$ & $\mathrm{R}$ & $\mathrm{R}$ & NA \\
\hline Piperacillin-tazobactam $(100 / 10 \mu \mathrm{g})$ & $\mathrm{R}$ & $\mathrm{R}$ & $\mathrm{R}$ & $\mathrm{S}$ & NA \\
\hline \multicolumn{6}{|c|}{ Inhibition zone in $\mathrm{mm}^{\mathrm{b}}$} \\
\hline Bacillus megaterium & $21 \pm 1.5$ & $26 \pm 1$ & $36 \pm 1$ & $24 \pm 1$ & $31 \pm 1$ \\
\hline Bacillus subtilis & $12 \pm 1$ & $18 \pm 2$ & $21 \pm 1$ & $15 \pm 1.5$ & $20 \pm 2$ \\
\hline Bacillus cereus & $12 \pm 1.2$ & $21 \pm 1$ & $36 \pm 1$ & $18 \pm 1$ & $14 \pm 1.5$ \\
\hline Bacillus thuringiesis & $14 \pm 1.5$ & $21 \pm 1$ & $21 \pm 1$ & $22 \pm 1$ & $18 \pm 0.6$ \\
\hline Bacillus lentus & $22 \pm 1.6$ & $22 \pm 1$ & $24 \pm 0.6$ & $32 \pm 1.5$ & $31 \pm 3$ \\
\hline Bacillus mycoides & NI & NI & NI & NI & NI \\
\hline Bacillus alvei & $34 \pm 1.5$ & $21 \pm 1$ & $39 \pm 1.5$ & $29 \pm 2.5$ & $48 \pm 2$ \\
\hline Bacillus polymyxa & $36 \pm 2.5$ & $17 \pm 0.6$ & $38 \pm 1$ & $17 \pm 4$ & $20 \pm 0.6$ \\
\hline Bacillus circulans & $21 \pm 1.5$ & $23 \pm 1$ & $39 \pm 1$ & $32 \pm 1$ & $32 \pm 2$ \\
\hline Micrococcus roseus & NI & NI & NI & NI & NI \\
\hline \multicolumn{6}{|c|}{ Inhibition zone in $\mathrm{mm}^{\mathrm{c}}$} \\
\hline ABM & $7.2+0.3$ & $7.5+0$ & NI & NI & NI \\
\hline ABS & $7.3+0.3$ & $7+0$ & NI & NI & NI \\
\hline $\mathrm{ABC}$ & $7+0.3$ & $7.3+0.3$ & NI & NI & NI \\
\hline $\mathrm{ABT}$ & $7.5+0$ & $7.2+0.3$ & NI & NI & NI \\
\hline $\mathrm{ABL}$ & $7.3+0$ & $7.5+0$ & NI & NI & NI \\
\hline $\mathrm{ABA}$ & $7.5+0.5$ & $7.3+0.3$ & NI & NI & NI \\
\hline
\end{tabular}

a: Comparing the antimicrobial susceptibility of a group of standard antibiotics (CLSI, 2017) against five human pathogenic strains 3 (control). $\mathrm{R}=$ Resistant, $\mathrm{S}=$ sensitive, $\mathrm{I}=$ intermediate, $\mathrm{NA}=$ Not applicable (for antibiotics that were not specific to the bacterial 4 strains), b: antimicrobial activity of the isolated Bacillus sp., NI= No inhibition, c: antimicrobial activity of purified amylase from 
some isolated Bacillus sp., ABM = amylase purified from Bacillus megaterium, ABS amylase purified from Bacillus subtilis, $\mathrm{ABC}=\quad 6$ amylase purified from purified Bacillus cereus, $\mathrm{ABT}=$ amylase purified from Bacillus thuringiesis, $\mathrm{ABL}=$ amylase purified from 7 Bacillus lentus, $\mathrm{ABA}=$ amylase purified from Bacillus alvei. Values expressed as mean $\pm \mathrm{SD}$. 


\section{Figure 1}

Optimization and purification conditions of amylase enzyme from selected Bacillus sp.

(A): The effect of temperature. B. megaterium, B. subtilis, and B. cereus showed maximum amylase production at $45^{\circ} \mathrm{C}$, while other isolates showed maximum amylase production at $55^{\circ} \mathrm{C}$. (B): The effect of incubation time. All isolates showed maximum amylase production after $24 \mathrm{~h}$ incubation. (C): The effect of $\mathrm{pH}$. All Bacillus isolates showed maximum amylase production at a pH of 8.0 except $B$. subtilis, which maximally produced amylase at a $\mathrm{pH}$ of 7.0. (D): The effect of starch concentration. $B$. subtilis and $B$. cereus had maximum amylase production at $1.5 \%$ soluble starch concentration. The remaining isolates had maximum amylase production at $2.0 \%$ soluble starch concentration. 


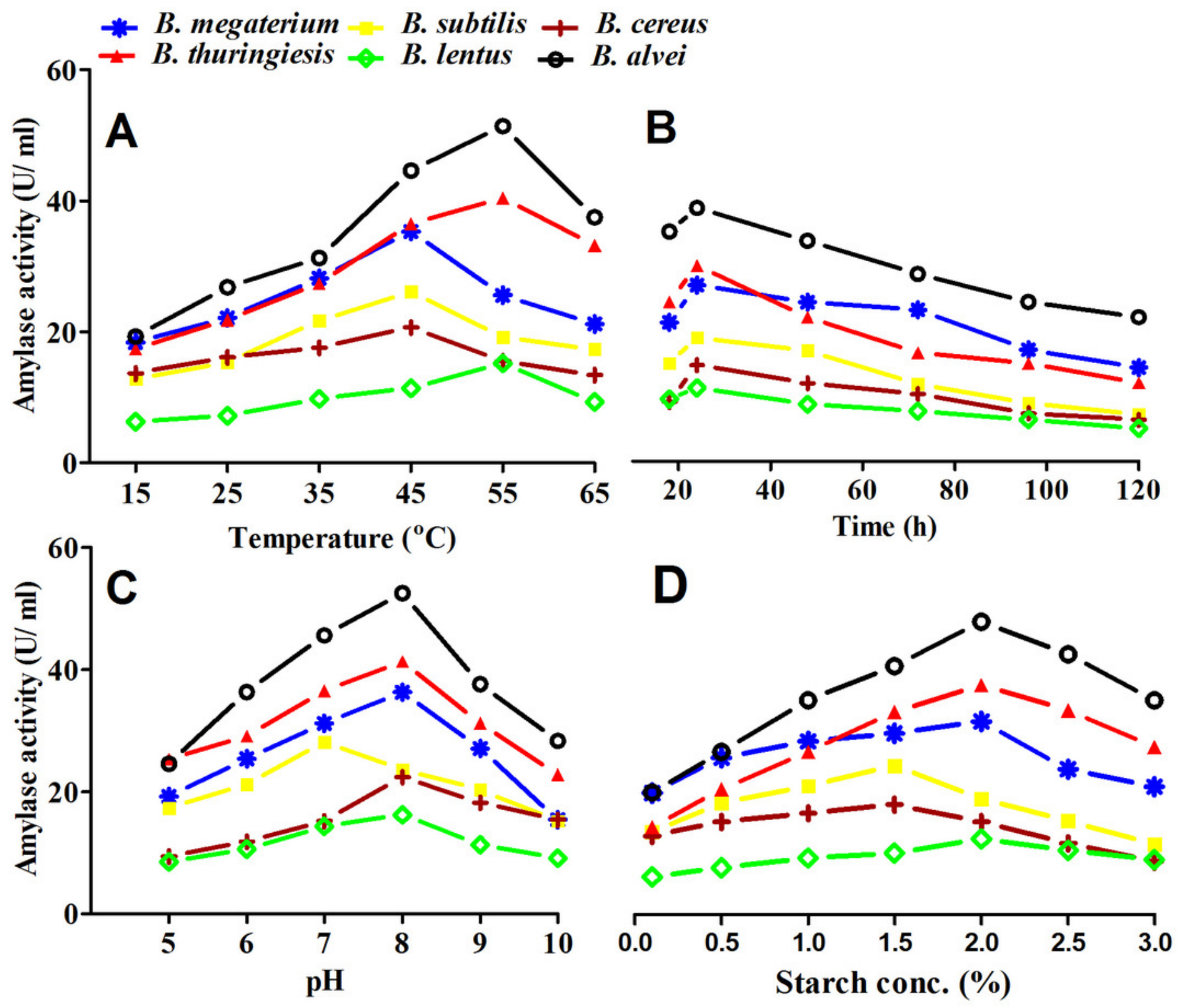


Figure 2

Elution profile of isolated Bacillus sp. on Sephadex G-200.

The figure shows the total protein concentrations $(\mathrm{mg} / \mathrm{ml}$ ) along with the enzyme activity ( $U$ / ml) for (A): B. megaterium; (B): B. subtilis; (C): B. cereus; (D): B. thuringiesis; (E): B. lentus; and (F): B. alvei.

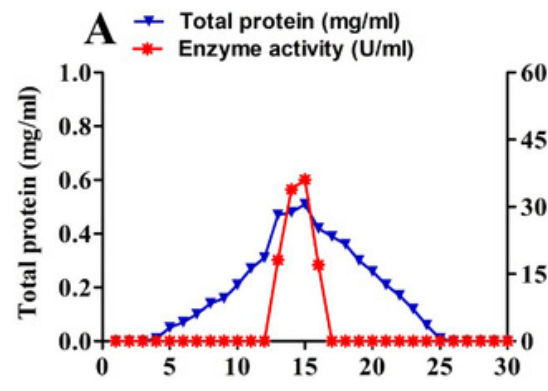

Fraction number

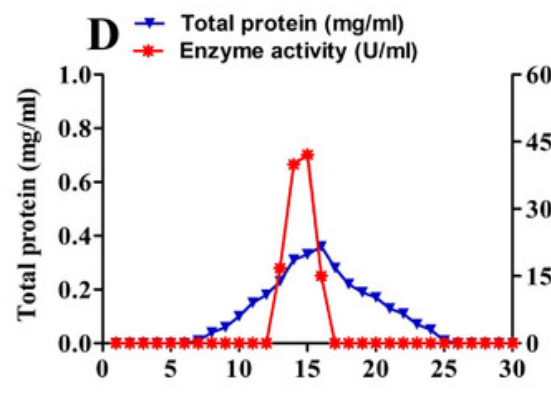

Fraction number
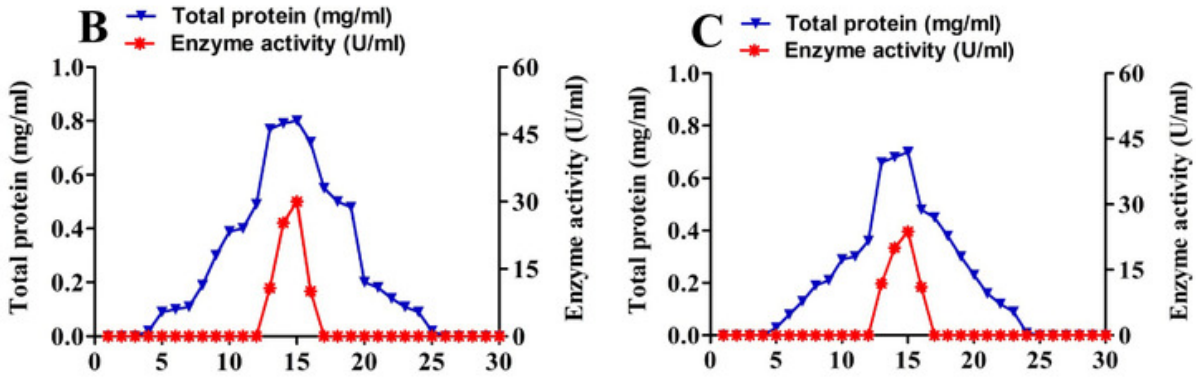

Fraction number

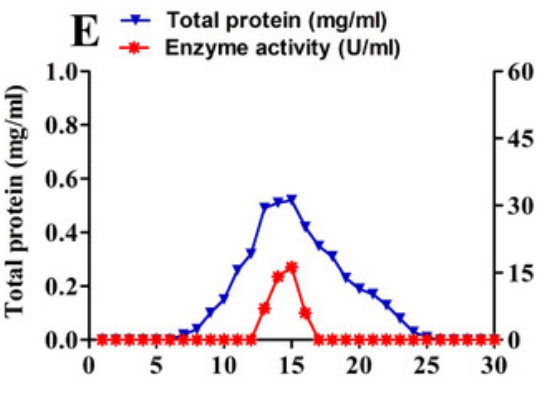

Fraction number
Fraction number

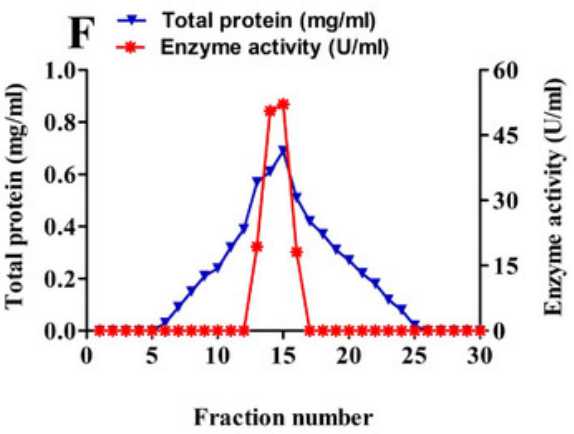


Figure 3

SDS-PAGE amylase profile for $B$. alvei and B. cereus.

Lane 1: molecular weight marker. Lane 2: amylase purified from $B$. alvei; Lane 3: amylase purified from $B$. cereus. 


$\begin{array}{ccc}\text { LANE } & \text { LANE } & \text { LANE } \\ 1 & 2 & 3\end{array}$

$65 \mathrm{KDa}$

$58 \mathrm{KDa}$

$46 \mathrm{KDa}$

$30 \mathrm{KDa}$

$25 \mathrm{KDa}$
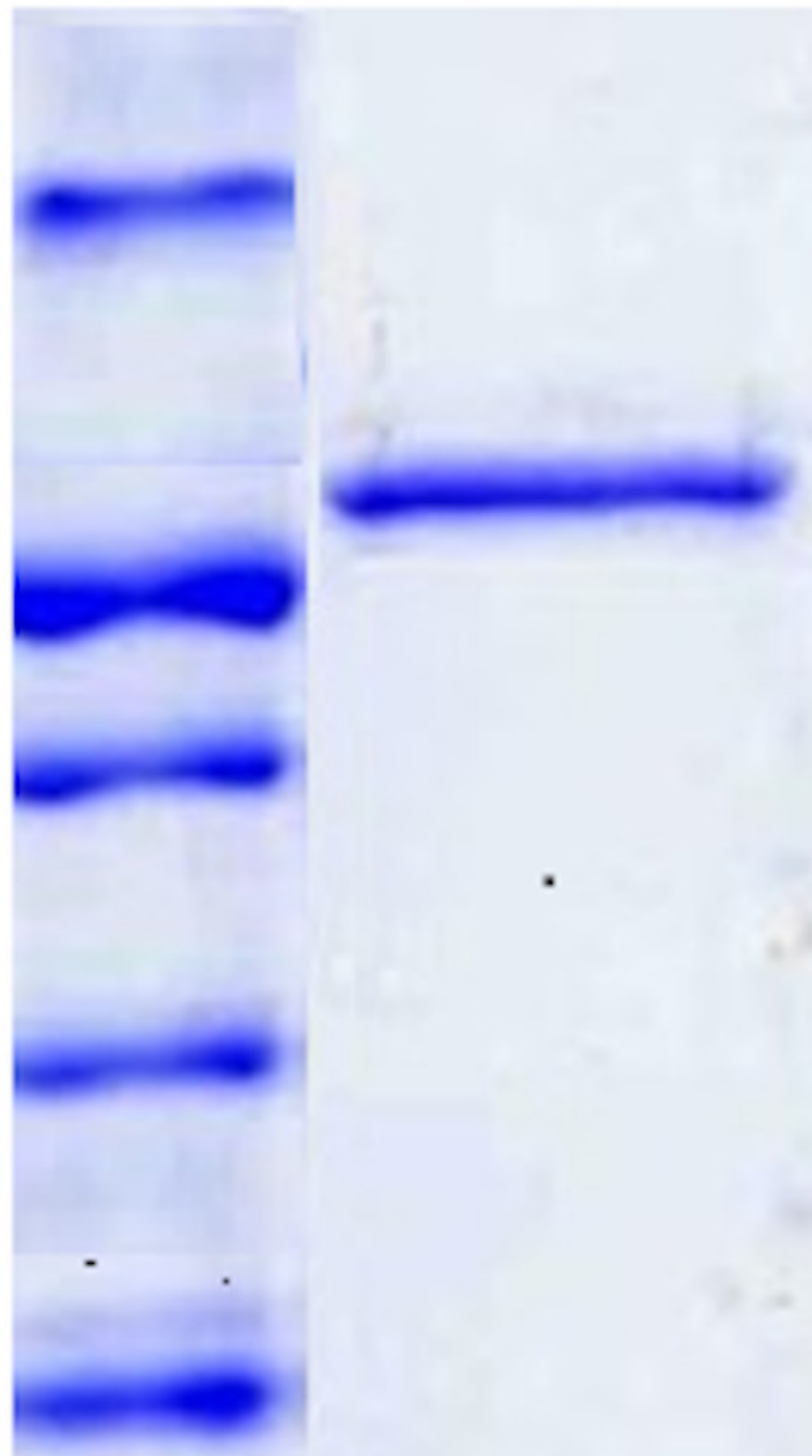

$17 \mathrm{KD}$ 
Figure 4

Comparing the antibiofilm activity of Bacillus-producing amylase-filtrate against some pathogenic bacteria after $24 \mathrm{~h}$ treatment.

The figure shows Bacillus sp. filtrate, T1: $B$. megaterium, T2: $B$. subtilis, T3: $B$. cereus, T4: $B$. thuringiesis, T5: B. lentus, T6: B. alvei, T7: B. polymyxa, T8: B. circulans. The tested pathogenic bacteria are (A) E. coli, (B) P. aeruginosa, (C) S. aureus (MRSA), (D) $K$. pneumoniae, and (E) A. baumanii. The figure shows the averages from at least three independent measurements. The error bars indicate the standard deviations using the least significant difference (LSD). The $1 \%$ LSD for E. coli, P. aeruginosa, S. aureus (MRSA), $K$. pneumoniae, and $A$. baumanii was $0.016,0.013,0.014,0.04$, and 0.17 , respectively. Significant differences between controls and treated samples are marked by asterisks. $\mathrm{P}<$ 0.05; Krustal-Wallis test and post hoc Bonferroni post-tests. Scales are different for A-C versus $\mathrm{D}$ and $\mathrm{E}$.
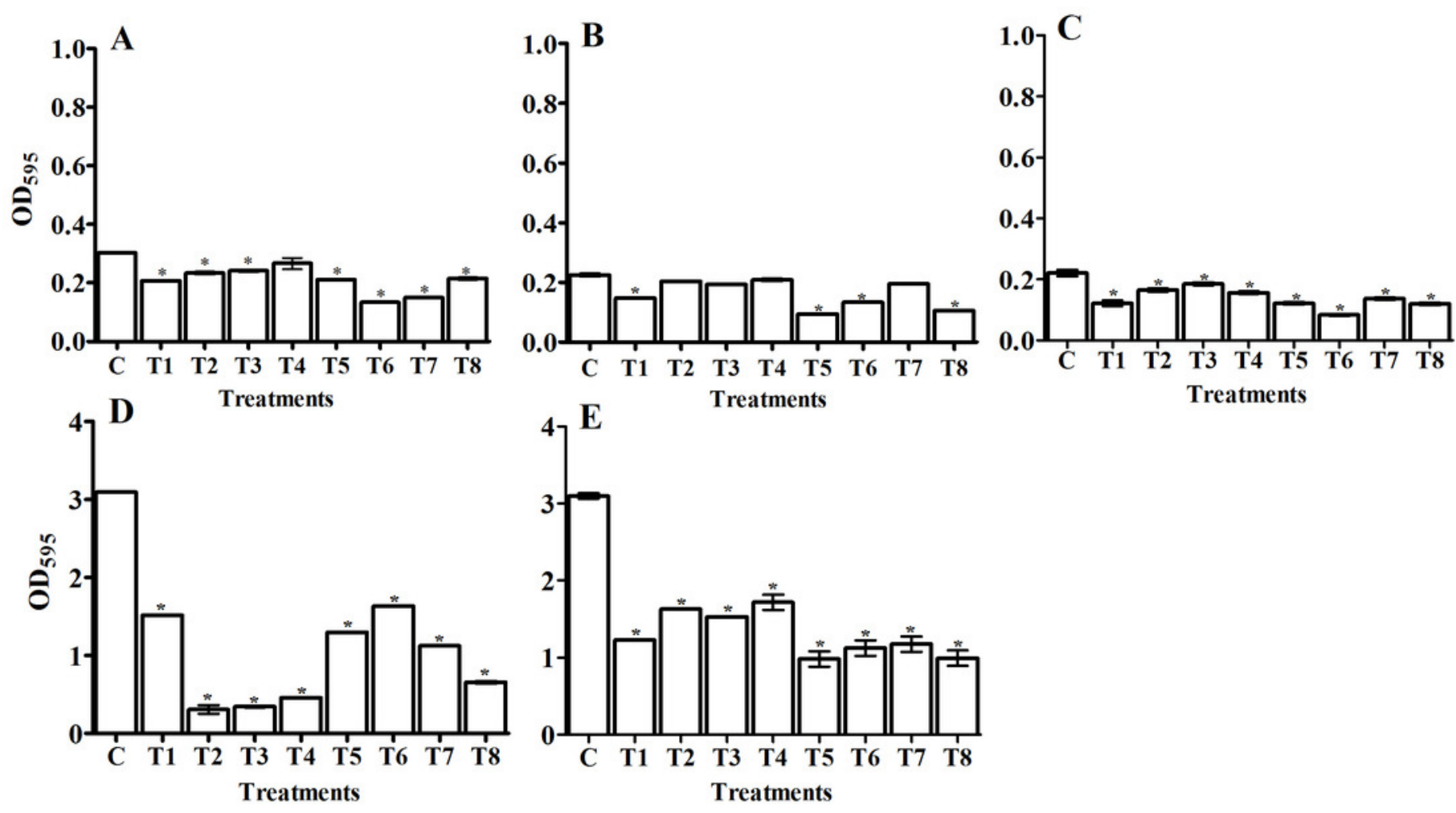

Treatments 


\section{Figure 5}

Comparing the antibiofilm activity of Bacillus-producing amylase-filtrate against some pathogenic bacteria after $48 \mathrm{~h}$ treatment.

The figure shows Bacillus sp. filtrate, T1: $B$. megaterium, T2: $B$. subtilis, T3: $B$. cereus, T4: $B$. thuringiesis, T5: B. lentus, T6: B. alvei, T7: B. polymyxa, T8: B. circulans. The tested pathogenic bacteria are (A) E. coli, (B) P. aeruginosa, (C) S. aureus (MRSA), (D) $K$. pneumoniae, and (E) A. baumanii. The figure shows the averages from at least three independent measurements. The error bars indicate the standard deviations using the least significant difference (LSD). An LSD of $1 \%$ for E. coli, P. aeruginosa, S. aureus (MRSA), $K$. pneumoniae, and $A$. baumanii was $0.027,0.014,0.013,0.08$ and 0.19 , respectively. Significant differences between controls and treated samples are marked by asterisks. $\mathrm{P}<$ 0.05; Krustal-Wallis test and post hoc Bonferroni post-tests. Scales are different for A-C versus $\mathrm{D}$ and $\mathrm{E}$.
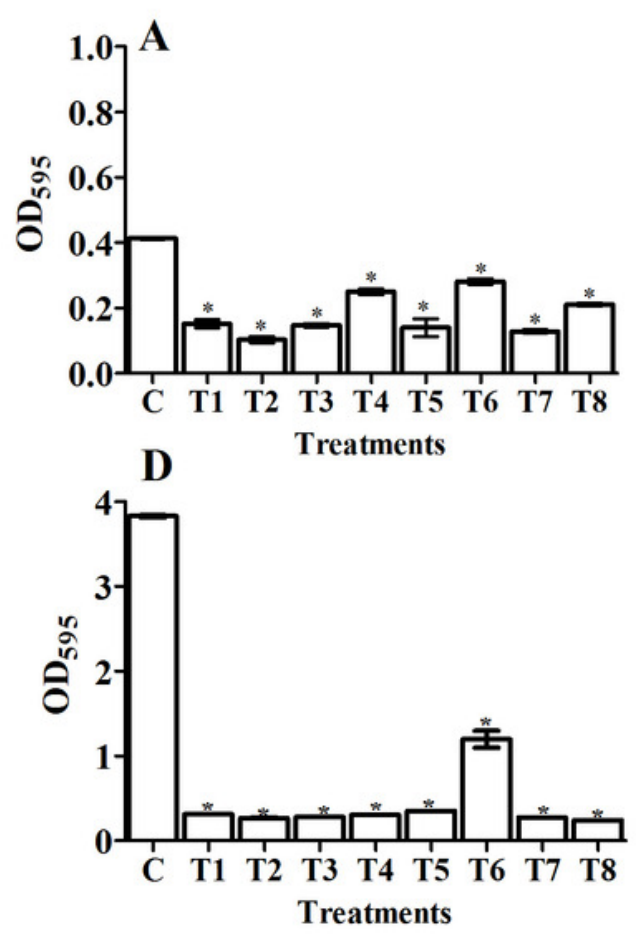

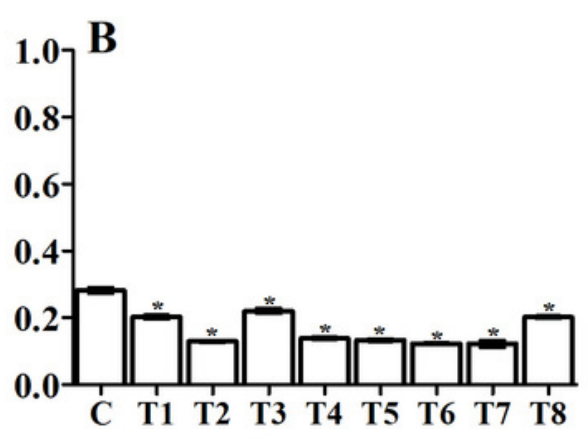

E

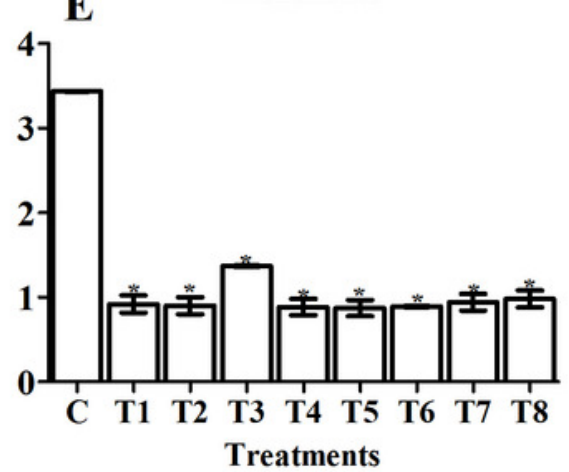

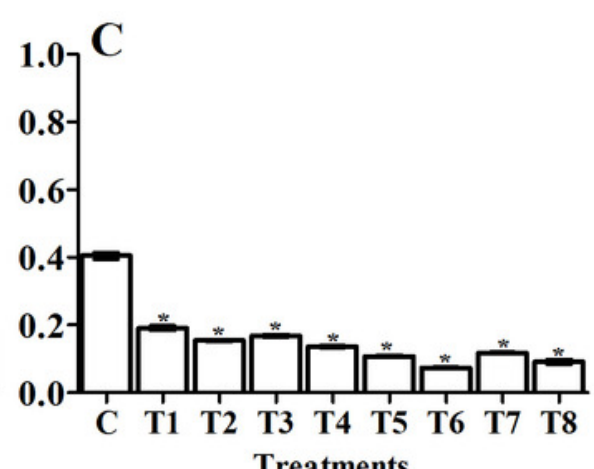

Treatments 
Figure 6

Comparing the antibiofilm activity of Bacillus- purified amylase enzyme against some pathogenic bacteria after $24 \mathrm{~h}$ treatment.

The figure shows Bacillus sp. filtrate, T1: $B$. megaterium, T2: $B$. subtilis, T3: $B$. cereus, T4: $B$. thuringiesis, T5: B. lentus, T6: B. alvei. The tested pathogenic bacteria are (A) E. coli, (B) $P$. aeruginosa, (C) S. aureus (MRSA), (D) K. pneumoniae, and (E) A. baumanii. The figure shows the averages from at least three independent measurements. The error bars indicate the standard deviations using the least significant difference (LSD). An LSD of $1 \%$ for E. coli, $P$. aeruginosa, S. aureus (MRSA), K. pneumoniae, and A. baumanii was $0.11,0.01,0.03,0.01$, and 0.02 , respectively. Significant differences between controls and treated samples are marked by asterisks. $\mathrm{P}<0.05$; Krustal-Wallis test and post hoc Bonferroni post-tests. Scales are different for $\mathrm{A}-\mathrm{C}$ versus $\mathrm{D}$ and $\mathrm{E}$.
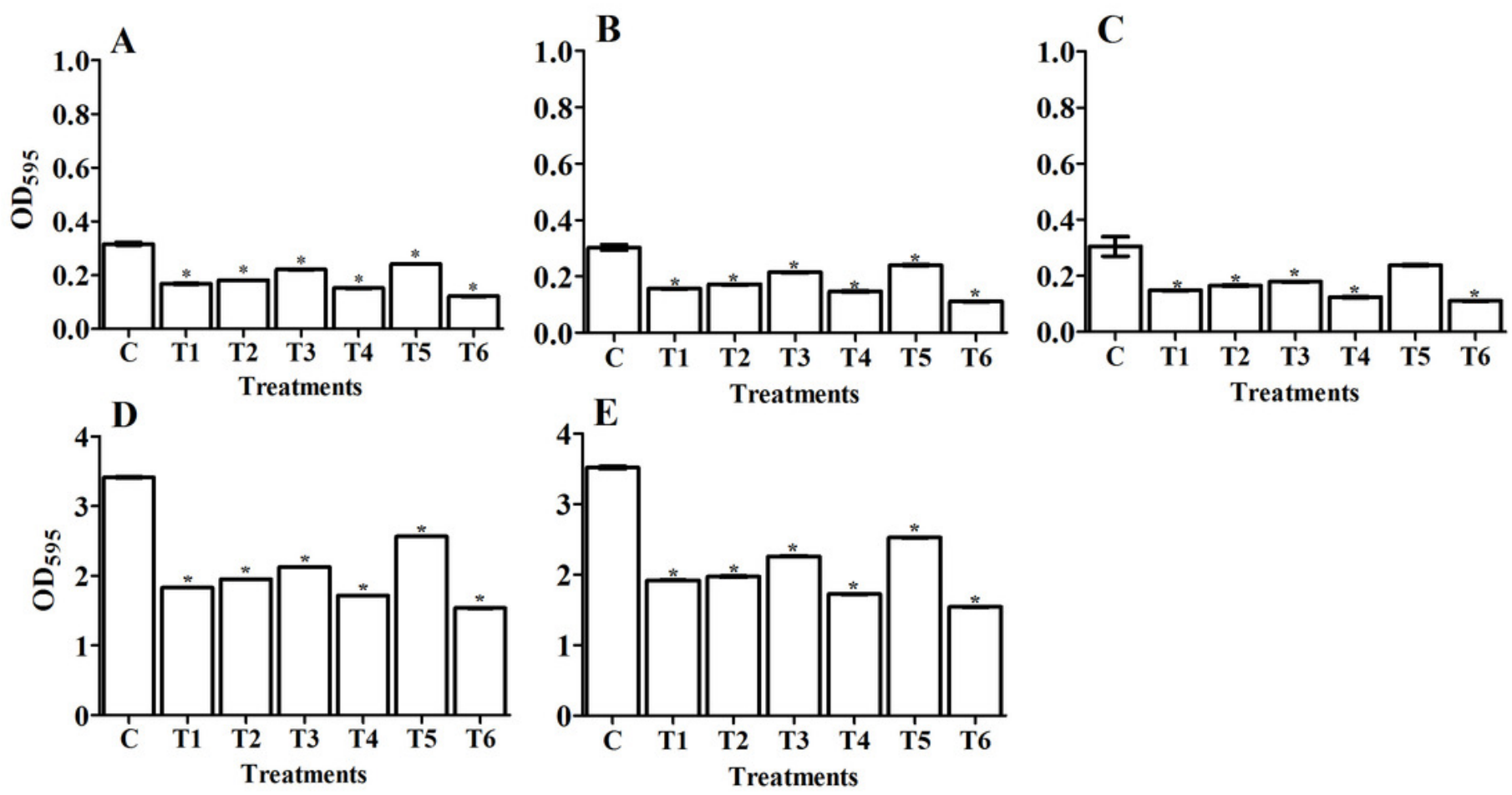


\section{Figure 7}

Comparing the antibiofilm activity of Bacillus- purified amylase enzyme against some pathogenic bacteria after $48 \mathrm{~h}$ treatment.

The figure shows Bacillus sp. filtrate, T1: $B$. megaterium, T2: $B$. subtilis, T3: $B$. cereus, T4: $B$. thuringiesis, T5: B. lentus, T6: B. alvei. The tested pathogenic bacteria are (A) E. coli, (B) P. aeruginosa, (C) S. aureus (MRSA), (D) K. pneumoniae, and (E) A. baumanii. The figure shows the averages from at least three independent measurements. The error bars indicate the standard deviations using the least significant difference (LSD). An LSD of $1 \%$ for E. coli, P. aeruginosa, S. aureus (MRSA), K. pneumoniae, and A. baumanii was 0.01, 0.009, 0.007, 0.018 , and 0.35 , respectively. Significant differences between controls and treated samples are marked by asterisks. $\mathrm{P}<0.05$; Krustal-Wallis test and post hoc Bonferroni post-tests. Scales are different for $\mathrm{A}-\mathrm{C}$ versus $\mathrm{D}$ and $\mathrm{E}$.
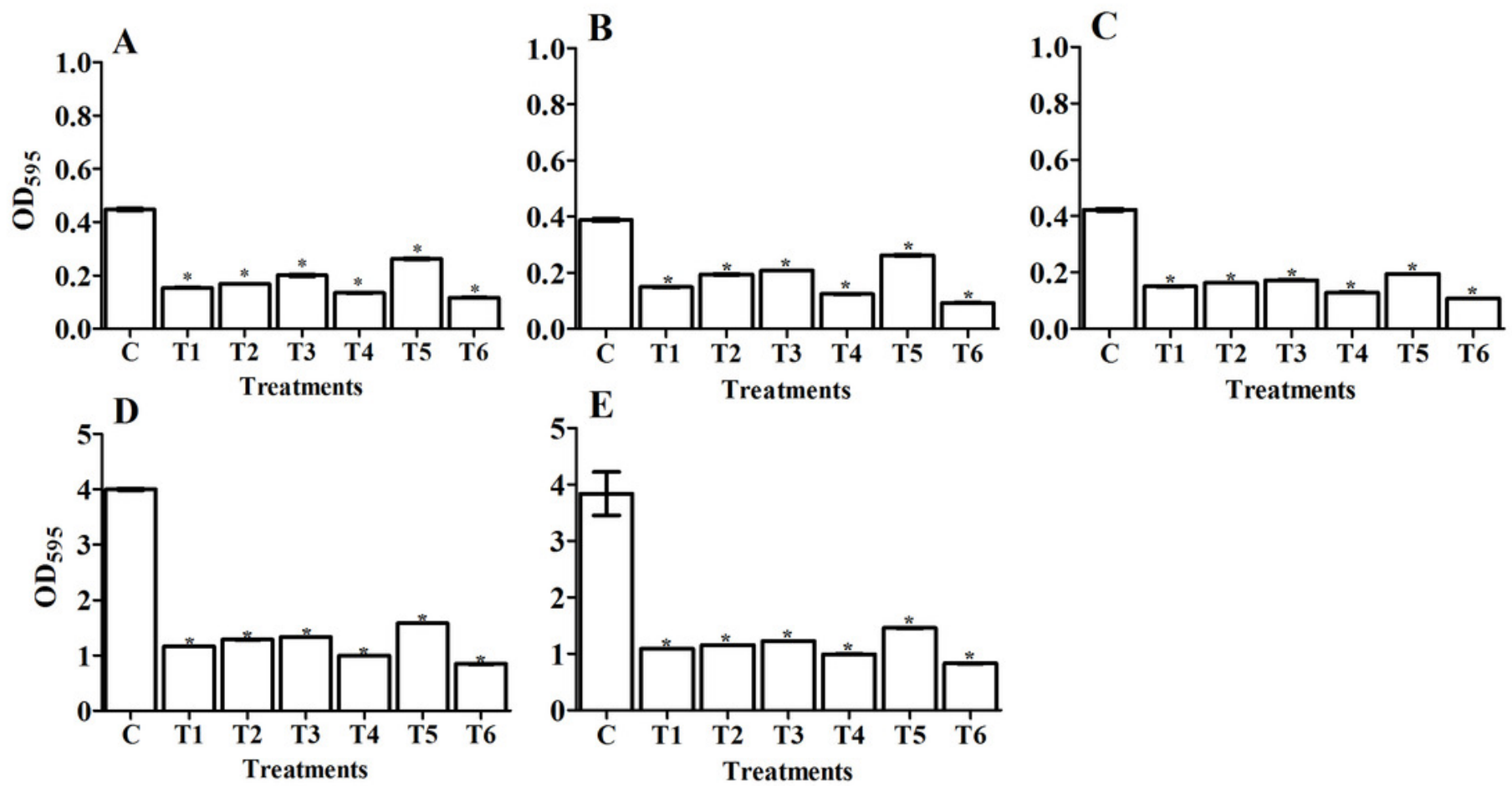